UNIVERSIDADE DE BRASÍLIA

FACULDADE DE DIREITO

PROGRAMA DE PÓS-GRADUAÇÃO EM DIREITO

BRUNA SANTOS COSTA

FEMINICÍDIOS E PATRIARCADO:

PRODUÇÃO DA VERDADE EM CASOS DE AGRESSORES AUTORIDADES DA SEGURANÇA E DEFESA DO ESTADO 
Dissertação apresentada ao Programa de PósGraduação em Direito da Universidade de Brasília como requisito parcial para a obtenção do título de mestra em Direito.

Orientadora: Profa. Dra. Debora Diniz 


\section{FEMINICÍDIOS E PATRIARCADO: PRODUÇÃO DA VERDADE EM CASOS DE AGRESSORES AUTORIDADES DA SEGURANÇA E DEFESA DO ESTADO}

Dissertação apresentada ao Programa de PósGraduação em Direito da Universidade de Brasília como requisito parcial para a obtenção do título de mestra em Direito.

A candidata foi considerada pela banca examinadora em 27 de março de 2017.

\footnotetext{
Professora Doutora Vanessa Canabarro Dios (membro externo) Anis - Instituto de Bioética
}

Professora Doutora Ela Wiecko Wolkmer de Castilho (membro interno)

Faculdade de Direito - Universidade de Brasília

Professora Doutora Lívia Gimenes Dias da Fonseca (membro suplente) Faculdade de Direito — Universidade de Brasília 


\section{RESUMO}

A presente pesquisa foi realizada em arquivo composto por processos de feminicídios cometidos por agentes de segurança e defesa do Estado, ocorridos no Distrito Federal, entre 2006 e 2011. Além de casos envolvendo policiais civis, militares, rodoviários federais, foram incluídos os casos de bombeiros militares e agentes do exército. O objetivo da pesquisa foi problematizar como a engrenagem punitiva produziu a verdade dos feminicídios, nos casos que envolveram agentes de segurança e defesa do Estado. A pergunta de pesquisa que guiou a minha análise foi: como foi produzida a verdade dos feminicídios quando cometidos por agentes de segurança e defesa do Estado? A verdade foi compreendida pela forma como as práticas judiciárias penais construíram, articularam e reconheceram os feminicídios em estudo. Como resultado, concluo que a verdade dos feminicídios foi produzida pelas práticas judiciárias sob uma moral patriarcal e a profissão dos agressores foi levada em consideração apenas para torná-los indivíduos perigosos. Isso mostra que há resistência em ampliar a discussão sobre violência doméstica e familiar contra as mulheres para além do espaço doméstico.

Palavras- chave: Feminicídio. Violência doméstica e familiar contra as mulheres. Agentes da segurança e defesa do Estado. Patriarcado. Gênero. 


\begin{abstract}
The present research was based on an archive composed of processes of feminicide committed by State security and defense agents, which took place in the Distrito Federal between 2006 and 2011. In addition to cases involving civil police, military police, and federal police, was included cases of military firefighters and army officers. The objective of the research was to problematize how the punitive gear produced the truth of feminicides, in the cases that involved the agents of security and defense of the State. The research question that guided my analysis was: how was the truth of feminicides produced when committed by state security and defense agents? The truth was understood by how the judicial practices constructed, articulated, and recognized the feminicides under study. As a result, I concluded that the truth of feminicides was produced by judicial practices under patriarchal morality and the profession of aggressors was taken into account only to make them dangerous individuals. This shows that there is resistance in broadening the discussion on domestic and family violence against women beyond domestic space.
\end{abstract}

Keywords: Feminicide. Domestic and family violence against women. Agents of the security and defense of the State. Patriarchy. Gender. 


\section{SUMÁRIO}

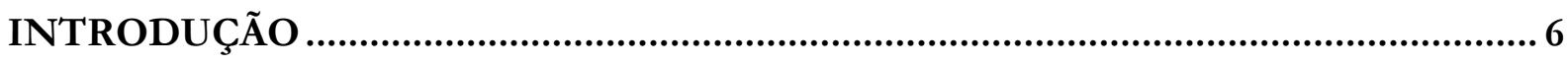

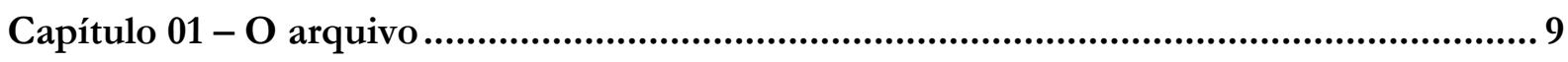

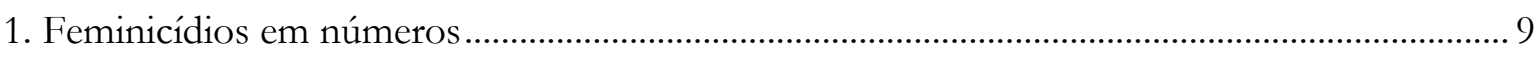

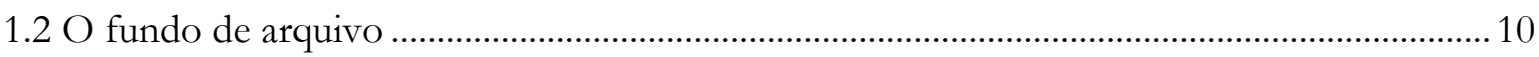

1.3 violência doméstica e familiar por agentes de segurança e defesa do estado .......................... 12

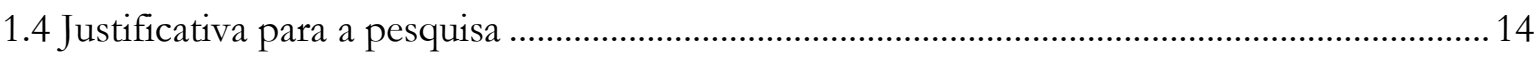

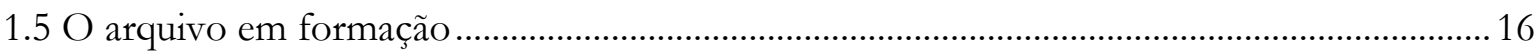

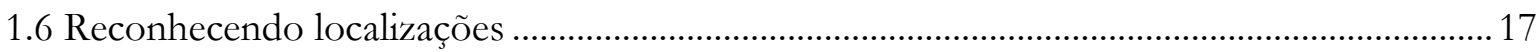

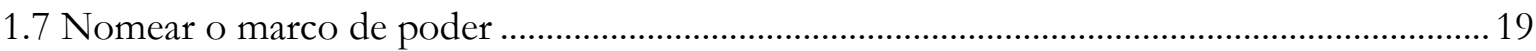

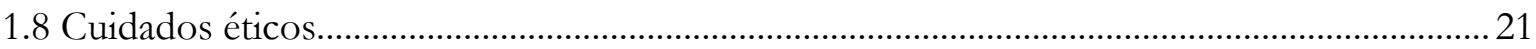

Capítulo 2 - As práticas judiciárias penais e a Violência Doméstica e Familiar .............. 24

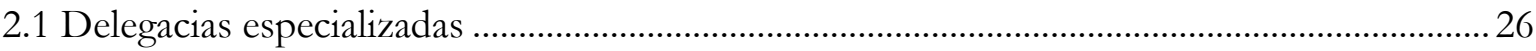

2.2 Lei $\mathrm{n}^{\circ} 9.099 / 95$

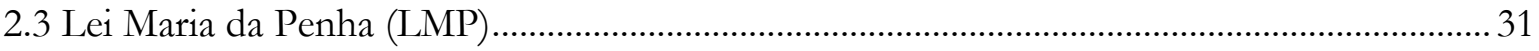

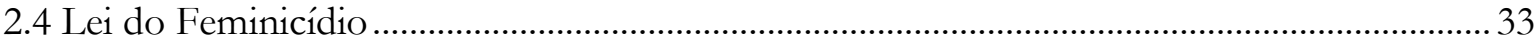

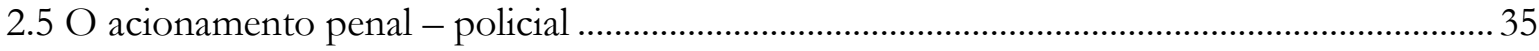

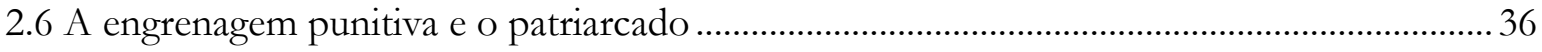

Capítulo 3 - A verdade dos feminicídios .............................................................................. 39

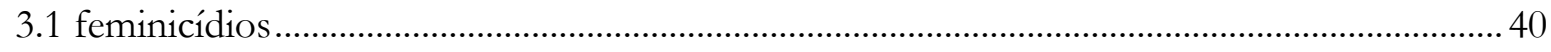

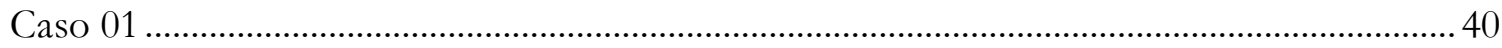

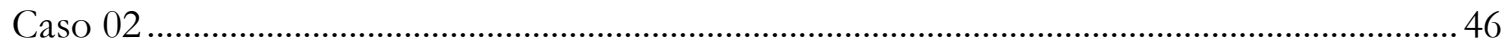

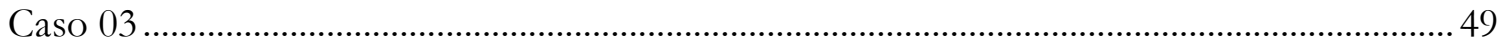

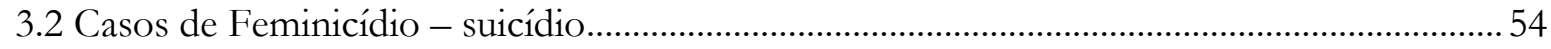

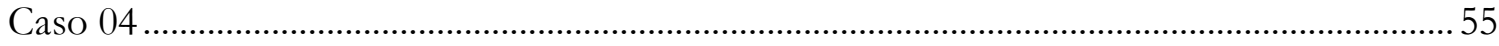

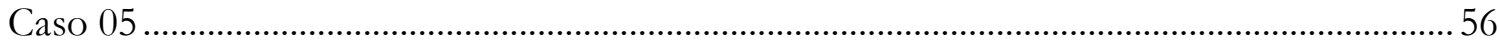

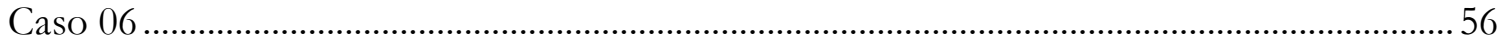

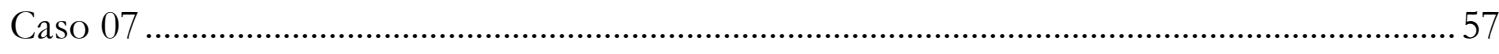

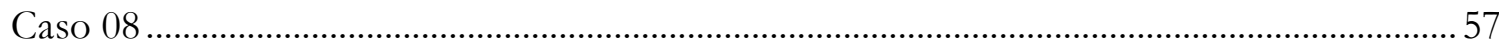

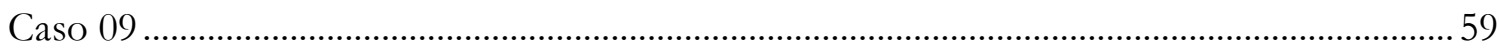

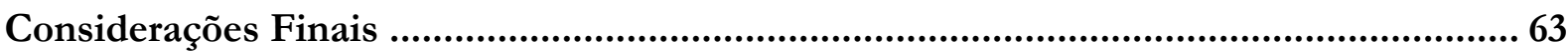

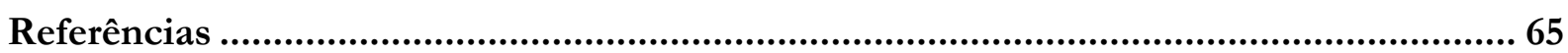




\section{INTRODUÇÃO}

Policial militar da Unidade de Polícia Pacificadora (UPP) do Rio de Janeiro matou a companheira e, em seguida, se matou. O crime ocorreu na residência do casal, na comunidade Vila do Céu. Segundo os vizinhos, eles moravam há seis anos no local e costumavam brigar por ciúmes, uma vez que a vítima era muito bonita. ${ }^{1}$

Soldado da Polícia Militar foi preso em flagrante após matar a ex- namorada a tiros. De acordo com testemunhas, o crime ocorreu porque o policial não aceitava o fim do relacionamento, que teria acabado após ele tê-la agredido. No dia dos fatos, o policial esperou a mulher chegar em sua casa à noite e disparou nove vezes contra ela. ${ }^{2}$

Estas são histórias recorrentes de serem encontradas nos noticiários, mulheres são mortas por seus maridos, companheiros e ex- parceiros todos os dias no Brasil. Cada história apresenta particularidades únicas, mas também carregam consigo características em comum: são histórias de corpos sexados no feminino que sofreram com o disciplinamento patriarcal na casa, na família, pelos familiares e afetos (BRASIL, 2006). Nas duas notícias que dão início a esse estudo, outra característica também chama atenção. Os agressores são policiais, isto é, agentes do Estado que devem promover a segurança da sociedade, inclusive a das mulheres. O fato da profissão dos agressores se destacar ocorre pelo lugar atribuído ao aparato policial no atual sistema de proteção de mulheres, já que a delegacia é a principal porta de entrada para que as vítimas de violência doméstica e familiar acessem seus direitos e busquem proteção. É na delegacia que as mulheres vão relatar abusos, buscar orientação e medidas para conter a violência sofrida.

Assim, saber quem é o agressor é importante para a análise e avaliação das políticas destinadas ao enfrentamento à violência doméstica e familiar contra a mulher, e para oferecer análises que permitam ao sistema de justiça oferecer respostas mais adequadas para que mulheres vivam vidas livres de violência. A presente pesquisa foi pensada a partir dessa perspectiva, tendo como objeto de análise o arquivo composto por processos de feminicídios cometidos por agentes de segurança e defesa do Estado, ocorridos no Distrito Federal, entre 2006 e 2011. Além de casos envolvendo policiais civis, militares, rodoviários federais, foram incluídos os casos de bombeiros

\footnotetext{
${ }^{1}$ Policial mata mulher, fere filha de 3 anos e depois se mata no Rio de Janeiro. Correio 24 horas, 23 jul. 2016. Disponível em: <http://www.correio24horas.com.br/detalhe/brasil/noticia/policial-mata-mulher-fere-filha-de-3-anos-e-depoisse-mata-no-rio-de-janeiro/?cHash=abf1ebdf3723f28bfb148159df05fde3 >. Acesso em 05 mar. 2017.

2 Por não aceitar fim do namoro, policial militar mata namorada a tiros em São Paulo. Correio 24 horas, 12 jan. 2017. Disponível em: <http://www.correio24horas.com.br/detalhe/categoria/noticia/por-nao-aceitar-fim-do-namoropolicial-militar-mata-namorada-a-tiros-em-sao-paulo/?cHash=9043a0cdc23a4ca199629f8d193d40bd>. Acesso em: 05 mar.2017.
} 
militares e agentes do exército, em razão do lugar comum que ocupam para a manutenção da segurança das pessoas e do Estado. Para o presente estudo, feminicídio será definido como a morte "de corpos sexados como mulheres pelo regime político do gênero em um marco patriarcal de poder" (DINIZ et al, 2015, p. 228).

Esta é uma pesquisa em arquivo, isso significa que os processos que o compõem serão analisados a partir da produção da verdade pelos discursos das práticas judiciárias penais (FOCAULT, 2009). A verdade que importa para o presente estudo é a que foi produzida pelos poderes- saberes para que os feminicídios fossem reconhecidos como crimes e os agressores punidos. As vítimas de feminicídios são as verdadeiras testemunhas "de como a moral patriarcal inscreve nos corpos a sentença de subordinação" (DINIZ, 2014), mas elas não podem nos contar as suas histórias, já que no presente arquivo não há vítimas sobreviventes. Assim, a biografia de cada uma delas é contada pela verdade produzida pelos discursos das práticas judiciárias.

Assim, o objetivo da presente pesquisa foi problematizar como a engrenagem punitiva produziu a verdade dos feminicídios, nos casos que envolveram os agentes de segurança e defesa do Estado. A tese que será defendida é a que a verdade dos feminicídios foi produzida pelas práticas judiciárias sob uma moral patriarcal e a profissão dos agressores foi levada em consideração apenas para torná-los indivíduos perigosos. Isso mostra que há resistência em ampliar a discussão sobre violência doméstica e familiar contra as mulheres para além do espaço doméstico.

No capítulo 01, descrevo como a presente pesquisa foi realizada. Nesse sentido, apresento a pesquisa guarda-chuva realizada pela Anis - Instituto de Bioética (2015), intitulada "Radiografia dos homicídios por violência doméstica contra a mulher no Distrito Federal", que mapeou a violência doméstica homicida no Distrito Federal, entre 2006 e 2011, na qual atuei como pesquisadora em campo. A partir da pesquisa da Anis (2015), foram selecionados todos os casos em que os agressores eram agentes da segurança e defesa do Estado, que passaram a compor o arquivo em análise. Além disso, apresento os marcos teóricos de análise dos dados da pesquisa, que utiliza a perspectiva teórica feminista. Ainda, apresento a revisão de literatura feita e os cuidados éticos utilizados.

No segundo capítulo, retomo o histórico de lutas do movimento feminista e de mulheres, que denunciou o gênero existente na violência da família, nas leis e no tratamento das vítimas pelo sistema de justiça. Além das principais políticas públicas em atenção à violência contra a mulher que foram conquistadas nos últimos anos - como as Delegacias Especializadas de Atendimento à Mulher - DEAMs, a Lei Maria da Penha e a Lei do Feminicídio - ainda, apresento 
as principais perspectivas teóricas sobre o funcionamento da engrenagem punitiva que inspiraram o presente trabalho.

Por fim, no terceiro capítulo, apresentarei os resultados da pesquisa realizada nos processos judiciais que compõem o arquivo em estudo. Serão apresentados e analisados os discursos das práticas judiciárias que produziram a verdade dos feminicídios, a luz da perspectiva teórica feminista e foucaultiana, e que permitiram a construção da tese da pesquisa. 


\section{CAPÍTULO 01 - O ARQUIVO}

\section{FEMINICÍDIOS EM NÚMEROS}

Conhecer os feminicídios no Brasil é tarefa difícil, uma vez que não há dados oficiais disponíveis e nem pesquisas realizadas que sejam sistemáticas para dimensionar quantas mulheres morreram pela violência de seus maridos, companheiros e ex- parceiros no país. Para Wânia Pasinato (2011), a falta de dados oficiais que possibilite contar as mulheres que morrem e os contextos das mortes é uma das principais dificuldades para os estudos sobre o tema.

Um dos estudos que buscou dimensionar os feminicídios foi o Mapa da Violência 2015, elaborado pela Faculdade Latino-Americana de Ciências Sociais (Flacso), que se dedicou a estudar a violência letal contra as mulheres e preencher a lacuna de dados sobre esse fenômeno. Essa pesquisa utilizou como fonte de dados as declarações de óbito do Sistema de Informações de Mortalidade (SIM), da Secretaria de Vigilância em Saúde (SVS) do Ministério da Saúde (MS), do período de 1980 a 2013. Por esses documentos foi possível identificar que nesse intervalo morreram 106.093 mulheres, vítimas de homicídios. Apenas em 2013, foram 4.762 mulheres mortas. Por meio das declarações de óbito foi possível saber dados pessoais das vítimas, como idade, sexo, estado civil, profissão, naturalidade e residência. Mas, não foi possível caracterizar os homicídios como feminicídios nos termos da Lei 13.104/2015 por falta de informações sobre o autor do crime e de sua relação com a vítima (WAISELFISZ, 2015).

Em razão da inexistência de dados ou fontes específicas, o Mapa da Violência utilizou como proxy para estimar os feminicídios do ano de 2013, os dados do Sistema de Informação de Agravos de Notificação (SINAN), que registra compulsoriamente os atendimentos de casos de violência do Sistema Único de Saúde (SUS) no campo das violências. No caso da violência contra a mulher, a Lei $n^{\circ}$ 10.778/2003 estabelece que devem ser notificadas qualquer conduta baseada no gênero que cause morte, dano, sofrimento físico, sexual ou psicológico, quando a mulher for atendida em serviços públicos e privados. A partir dos dados do SINAN, foi calculada a proporção de mulheres vítimas de familiares ou parceiros e projetou-se a proporção sobre os homicídios ocorridos em 2013. Das 4.762 vítimas mulheres registrado em 2013 pelo SIM, 50,3\% teriam sido praticadas por um familiar direto da vítima, ou seja, seriam feminicídios (WAISELFISZ, 2015).

Apesar de chamarem atenção, a estimativa de feminicídios ocorridos em 2013 apresentada pelo Mapa da Violência é problemática, pois utiliza para o cálculo dos feminicídios dados do SINAN que são precários para estimar a violência doméstica e familiar do Brasil. Isso 
porque, a despeito da notificação do SINAN ser compulsória pelo gestor de saúde do SUS, nos termos da legislação, na prática, ela não é feita em todos os lugares e nem para todos os casos (GARCIA, 2016). Ou seja, muitos casos de violência doméstica e familiar não são considerados pelo SINAN, o que prejudica o conhecimento da magnitude do fenômeno. O SINAN apresenta problemas de cobertura e de subnotificação, de forma que é uma fonte de dados limitada para estimar os feminicídios ocorridos no Brasil (WAISELFISZ, 2015).

Ainda restam dúvidas quanto a dimensão da violência doméstica e familiar no Brasil, por não existir registro de dados oficiais confiáveis sobre esse fenômeno. Dessa forma, pesquisas localizadas em algumas regiões do país são importantes por permitirem mapear os números da violência de forma mais próxima da realidade, ainda que de forma pontual. Nessa perspectiva, está a pesquisa guarda-chuva realizada pela Anis - Instituto de Bioética, a qual o presente estudo se vincula. Esta pesquisa mapeou as mortes de mulheres por violência doméstica e familiar no Distrito Federal, no período de 2006 a 2011, e apresentou dados sobre o fenômeno em estudo.

\subsection{O FUNDO DE ARQUIVO}

Este estudo analisou parte dos processos judiciais do fundo de arquivo da pesquisa intitulada "Radiografia dos homicídios por violência doméstica contra a mulher no Distrito Federal", realizada pela Anis - Instituto de Bioética (2015), em que participei como uma das pesquisadoras em campo. Fundo de arquivo é uma categoria utilizada para representar o conjunto de documentos que se acumularam "de maneira orgânica, automática, no exercício das atividades de uma pessoa física ou jurídica, privada ou publica, e cuja conservação respeita esse crescimento sem jamais desmembrá-lo" (FARGE, 2009, p.12). No caso da pesquisa, o fundo de arquivo foi composto por laudos cadavéricos, processos judiciais e inquéritos policiais referentes às mortes violentas de mulheres. Apesar de se tratarem de documentos públicos, a realização da pesquisa só foi possível em razão da colaboração do Ministério Público do Distrito Federal e Territórios (MPDFT), que intermediou o acesso das pesquisadoras aos processos judiciais e inquéritos policiais, nos diversos órgãos do aparato policial - judiciário do DF.

A pesquisa teve como marco inicial o ano de implementação da Lei Maria da Penha, 2006, e como marco final o ano de 2011. Primeiro, foram recuperados todos os laudos cadavéricos por morte violenta de mulheres, desse período, no IML/DF, o que totalizou 338 mortes. Em seguida, foram buscados os inquéritos e ações penais correspondentes às mortes nas 12 varas do 
Tribunal do Júri do DF. Desse total, não foram consideradas 37 mortes, cujos processos judiciais estavam sendo julgados em circunscrições judiciais de outros estados próximos (Minas Gerais, Goiás, Bahia), e 26 casos em que os acusados eram menores de idade e, por isso, os processos eram protegidos por segredo de justiça.

Assim, o universo da pesquisa passou a totalizar 275 mortes. Destes foi possível identificar que 121 casos não eram de violência doméstica, já que as mortes ocorreram por causas diversas, como latrocínios, relacionadas ao tráfico de drogas, por erro de execução, ${ }^{3}$ entre outras; 47 mortes correspondiam a inquéritos policiais que tramitavam sem autoria certa ou que foram arquivados por falta de autoria. Nos termos da Lei Maria da Penha, para identificar a violência doméstica e familiar é necessário conhecer a relação entre agressor e vítima, por isso, estes últimos casos não foram utilizados; 11 eram laudos cadavéricos em que não foram localizados registros de inquéritos policiais ou processos judiciais em curso. Nestes, a morte violenta da mulher não teve nenhum desdobramento investigatório ou judicial, por isso também foram descartados. Diante disso, foi possível verificar que em 96 casos as mortes das mulheres se deu por violência doméstica e familiar, ou seja, 1 em cada 3 mulheres morreu por feminicídio.

Das 96 mortes analisadas, em 12 o feminicídio da mulher foi seguido pelo suicídio do agressor. Esses processos chamaram atenção pelo desfecho do crime e também por serem casos em que metade deles, em 06 feminicídios - suicídios, os agressores eram autoridades da segurança e defesa do Estado. Ou seja, eram policiais, agentes do exército e bombeiros militares. Esse achado de pesquisa levou ao retorno ao fundo de arquivo para localizar todas as mortes produzidas por agentes da segurança e defesa do Estado. ${ }^{4}$ Foram encontrados 09 feminicídios com essas características, sendo que em 06 ocorreu o duplo feminicídio- suicídio e em 03 houve feminicídio sem suicídio do agressor. Com autorização institucional da Anis, obtive acesso aos 09 casos de feminicídios por agentes da segurança e defesa do Estado, que formaram o arquivo da presente pesquisa.

\footnotetext{
3 “Art. 73 - Quando, por acidente ou erro no uso dos meios de execução, o agente, ao invés de atingir a pessoa que pretendia ofender, atinge pessoa diversa, responde como se tivesse praticado o crime contra aquela, atendendo-se ao disposto no $\llbracket 3^{\circ}$ do art. 20 deste Código. No caso de ser também atingida a pessoa que o agente pretendia ofender, aplica-se a regra do art. 70 deste Código" (BRASIL. 1940).

${ }_{4}^{4}$ Para a Resolução CNS 466/2012, achados de pesquisas são "fatos ou informações encontrados pelo pesquisador no decorrer da pesquisa e que sejam considerados de relevância para os participantes ou comunidades participantes".
} 


\subsection{VIOLÊNCIA DOMÉSTICA E FAMILIAR POR AGENTES DE SEGURANÇA E DEFESA DO ESTADO}

$\mathrm{Na}$ fase de revisão de bibliografia sobre o tema específico, foram encontradas poucas pesquisas com a perspectiva da violência doméstica e familiar cometida por agentes de segurança e defesa do Estado. A maioria dos estudos foi produzida nos Estados Unidos, com o enfoque específico na violência cometida por policiais.

Alguns estudos utilizaram a categoria de cultura policial para entender a ocorrência de violência doméstica e familiar por policiais (JOHNSON et al, 2005; SGAMBELLURI, 2000; AMMONS, 2005; MIRANDA; ALFONSÍN, 2015; BLUMENSTEIN et al, 2011). A cultura policial é entendida como o que daria identidade própria a organização policial, mas não poderia ser considerada homogênea, nem universalmente válida ou imutável. ${ }^{5}$ Os estudos não afirmaram que a cultura policial teria uma relação de causalidade com a violência doméstica, mas sim que mediaria a ocorrência da violência, uma vez que existiriam condições específicas para o exercício da violência decorrentes do ethos policial.

Outros estudos mostraram dados numéricos sobre o tema. Em 1991, a pesquisadora Leanor Boulin Johnson divulgou os resultados do seu estudo que relacionava estresse policial e os seus efeitos na família. A pesquisa foi realizada com amostra por conveniência de policiais, isto é, a amostra utilizada foi não probabilística e os participantes foram escolhidos pela facilidade de acesso da pesquisadora, num total de 728 policiais. Ela encontrou que 40\% dos policiais responderam que nos últimos seis meses anteriores haviam se comportado de forma violenta contra suas esposas e filhos. Na pesquisa não fica claro se a violência considerada por ela foi a física, psicológica, sexual ou patrimonial. No ano seguinte, Peter H. Neidig et al (1992) conduziram uma pesquisa que chegou a resultados semelhantes. Com base em uma amostra por conveniência, composta por 385 policiais homens e 40 policiais mulheres, eles encontraram que aproximadamente $40 \%$ dos policiais reportaram pelo menos um episódio de agressão física durante conflitos domésticos e familiares no ano anterior.

Apesar dos resultados encontrados nas duas pesquisas mostrarem que há número alto de policiais que cometeram violência doméstica e familiar contra a mulher, pesquisas realizadas com amostra por conveniência tem limitações por utilizarem amostra não representativa da

\footnotetext{
${ }^{5}$ André Rosemberg (2012) explica que a cultura policial pode ser entendida como "um guia, composto de normas informais que orientam a ação dos policiais (principalmente os de menor patente), e que opera nos interstícios das rígidas regras organizacionais, longe dos olhos supervisores" (p. 69). Dessa forma, a cultura policial "funcionaria como um código informal e tácito de regulagem da atuação do policial diante das situações que se apresentam, moldando a maneira como ele se relaciona com os colegas, com a instituição e com o público” (p. 70).
} 
população, uma vez que as características apresentadas estão vinculadas aos participantes selecionados e não à população em geral. Dessa forma, não é possível a partir destas pesquisas fazer afirmações gerais com rigor estatístico sobre a população em estudo. De qualquer forma, pesquisas com amostra por conveniência possibilitam apresentar um retrato do que pode ser o universo estudado e podem servir de base para que outros estudos sejam realizados.

Já no Brasil, foi encontrada a pesquisa de mestrado de Renata Cardoso (2015), do programa de pós-graduação em desenvolvimento, sociedade e cooperação internacional, do Centro de Estudos Avançados Multidisciplinares da Universidade de Brasília (UnB). A pesquisa intitulada "Homens autores de violência contra parceiros íntimos: estudo com policiais militares do Distrito Federal" analisou a atuação da PMDF nos casos de violência doméstica e familiar praticadas pelos integrantes da corporação. Para isso, foram analisados os procedimentos administrativos de sindicâncias realizadas no período de 2012 a 2014.

A escolha do período em análise se deu em razão da implementação da IN 003/2011/DCC/ PMDF em 2011, instrumento que regulamentou as normas de conduta adotadas pela corporação quando da prática de violência contra a mulher por seus agentes. Foram encontradas 264 sindicâncias por violência doméstica. O estudo ainda mostrou que, dos policiais militares que responderam a procedimento administrativo de sindicância por violência doméstica, $94,8 \%$ não foram punidos administrativamente. Em $85 \%$ das sindicâncias houve arquivamento por inexistência do fato ou autoria. As vítimas eram, em sua maioria, esposas, companheiras, exesposas e ex- companheiras e a principal motivação para a violência foi o fim do relacionamento.

Os dados da pesquisa chamam atenção não apenas pelos números encontrados de violência doméstica e familiar cometidas por policiais militares do DF, mas também pelo tratamento institucional dado à violência quando se trata de um de seus agentes. Ainda que uma normativa interna tenha sido especificamente criada para identificar policiais violentos em casa e na família, na prática, não houve a sua implementação. Os policiais não foram responsabilizados e as vítimas não foram protegidas. Não foram encontradas outras pesquisas brasileiras que tratem do tema e que poderiam servir de comparação com o Distrito Federal.

Assim, estudar o tema específico da violência doméstica e familiar cometida por agentes da segurança e defesa do estado é explorar um universo de estudo ainda pouco conhecido e investigado. 


\subsection{JUSTIFICATIVA PARA A PESQUISA}

Como já relatado, a dificuldade de estudar o fenômeno da violência doméstica e familiar cometida por agentes da segurança e da defesa do Estado foi sentida logo no início do mestrado, na fase de revisão de literatura, em que verifiquei a pouca produção bibliográfica sobre esse tema específico. A escassa literatura existente foi produzida predominantemente nos Estados Unidos, em específico sobre violência doméstica e familiar cometida por policiais, e foi encontrada apenas uma pesquisa com esse enfoque no Brasil. Em geral, estudos centrados na violência dos agentes de segurança e defesa do Estado têm como perspectiva a violência ocorrida no espaço público, que decorre da atuação profissional desses agentes, especialmente a de policiais, já que o aparato policial tem como traço definidor a autorização para uso da força, inclusive a letal (BITTNER, 2003). Esse atributo tem se mostrado problemático na prática, pois possibilita que muitos abusos aconteçam. ${ }^{6}$

Na perspectiva das mulheres, muitos estudos se dedicaram a analisar o funcionamento das DEAMs e das demais delegacias no enfrentamento à violência doméstica e familiar contra a mulher (MACHADO, 2002; PASINATO, 2004; NOBRE; BARREIRA, 2008), mas não quanto à possibilidade de policiais serem agressores. Em um primeiro momento, poderia concluir que a existência de poucas pesquisas com a perspectiva na violência doméstica e familiar cometida por agentes de segurança e defesa do Estado se sustentaria por não existir relação entre a violência no âmbito privado cometida por esses agentes e a sua atuação profissional, de forma que não faria sentido relacionar os dois fenômenos.

No entanto, levando em conta as contribuições teóricas feministas, tal conclusão não se sustenta, uma vez que desconsidera gênero como categoria de análise e reifica a dicotomia público - doméstico. As teóricas feministas ao incluírem gênero como categoria de análise, demonstraram que a divisão entre espaço doméstico, esfera da vida inacessível e protegida pelo direito a intimidade, e o espaço público, vida não doméstica, era perversa para as mulheres, pois como o espaço público era predominantemente atribuído aos homens, e o doméstico delimitado às mulheres, a sociedade era compreendida a partir da perspectiva masculina, baseada em pressupostos sobre a natureza dos sexos e das performances dominantes de homens e mulheres

\footnotetext{
${ }^{6}$ De acordo com o $9^{\circ}$ Anuário Brasileiro de Segurança Pública, a cada 3 horas uma pessoa foi morta pela polícia em 2014. Disponível em < http://www.forumseguranca.org.br/storage/9_anuario_2015.retificado_.pdf> Acesso em 01 fev. 2017.
} 
(OKIN, 2008). Dessa forma, era invisibilizada a experiência feminina, inclusive a referente a violência vivida no lar.

Assim, as teóricas feministas mostraram a artificialidade da dicotomia públicodoméstico, no sentido de que o que ocorre na casa não está desvinculado da dinâmica de poder da esfera pública. A divisão entre doméstico e não -doméstico não é neutra, ela gera desigualdades baseadas no gênero. Nesse sentido, o slogan "o pessoal também é político" sintetiza a ideia de que o âmbito doméstico não poderia ser interpretado de forma isolada do público, ou seja, as práticas que geram desigualdades entre homens e mulheres só podem ser inteligíveis quando há referência as duas esferas (OKIN, 2008). Ao formular a pergunta sobre a mulher em pesquisas é necessário utilizar gênero como categoria de análise e levar em conta a casa como espaço da violência. ${ }^{7}$ Com base nisso, parto da ideia de que a família e o espaço público não devem ser considerados de forma isolada um do outro, mas como em permanente relação.

O enfoque desse trabalho justifica-se nesse sentido, por considerar que o âmbito doméstico, da família, e o âmbito público, da atuação profissional dos agressores, não devem ser vistos como esferas separadas, mas como tendo relação um com o outro. A violência doméstica e familiar contra mulheres cometidas por agentes de segurança e da defesa do estado podem ter efeitos na atuação profissional, especialmente se considerarmos o papel de destaque do aparato policial no enfrentamento à violência doméstica e familiar. A Lei 11.340/06, mais conhecida como Lei Maria da Penha (LMP), conferiu poderes importantes para a polícia na resposta à violência. A delegacia é a principal porta de entrada para as vítimas de violência, é lá que as mulheres vão relatar abusos, buscar orientação e medidas de proteção e contenção da violência sofrida. Dessa forma, a violência cometida por esses agentes no âmbito doméstico deve ser objeto de investigação.

O presente estudo pretende ampliar o enfoque dado para as pesquisas sobre violência doméstica e familiar e sobre o funcionamento do sistema de justiça criminal, uma vez que pretendo problematizar como a engrenagem punitiva produz a verdade dos feminicídios quando se trata de agentes que também são responsáveis pelo enfrentamento à violência doméstica e familiar contra as mulheres.

\footnotetext{
7 “A pergunta pela mulher indaga sobre as implicações genéricas de uma prática ou regra social: as mulheres foram desconsideradas? em que sentido? como essa omissão pode ser corrigida? o que muda ao fazê-la? No direito, formular a pergunta pela mulher implica examinar como o direito falha ao não levar em conta as experiências e valores que parecem mais comuns às mulheres que aos homens”. (BARTLETT, 2011, p. 32 - tradução livre).
} 


\subsection{O ARQUIVO EM FORMAÇÃO}

A presente pesquisa teve início com a leitura dos 09 processos de feminicídios selecionados. O passo seguinte foi o da coleta de dados com organização das informações em uma tabela com questões relativas ao perfil da vítima, do agressor, do crime e do julgamento. Gesto este que Arlette Farge (2009) descreve como o do despojamento do arquivo e que torna "possível outra narração do real” (p.64). O gesto seguinte ao do despojamento, foi o da seleção do que importava, recolhendo o que se diferenciava nos dados disponíveis, identificando o que se destacava e o que se escondia como vestígio de um acontecimento.

A dificuldade nessa etapa foi saber o que selecionar e o que abandonar. Como pesquisadora que esteve presente no desenvolvimento da pesquisa da Anis e que participou de todas as etapas do estudo - análise de laudos cadavéricos, busca de processos judiciais e inquéritos de feminicídios nas varas do Tribunal do Júri, coleta e análise de dados - o risco para mim era o alertado por Arlete Farge (2009), o de estar tão imersa pelo arquivo a ponto de não conseguir mais interrogá-lo. Assim, foi necessário estar vigilante para manter a distância necessária com o arquivo, além de manter a permanente desconfiança da identificação entre o que o ele mostrava e o que eu esperava encontrar nele.

Em uma primeira tentativa de aproximação, a minha intenção era entender o porquê dos feminicídios do Distrito Federal terem como agressores muitos agentes da segurança e defesa do estado, além das particularidades dos crimes, especialmente, a prevalência do duplo feminicídio - suicídio para esses agressores, já que dos 12 casos de feminicídio - suicídio, em 06 o agressor era agente da segurança e defesa do estado. No entanto, percebi que o importante no estudo em arquivo não é saber se os fatos relatados ocorreram exatamente da forma descrita nos processos, mas sim entender como se articulou aquela narrativa pelos poderes- saberes das práticas judiciárias penais. Ou seja, como se produziu a verdade dos feminicídios (FARGE, 2009; FOUCAULT, 2009).

O arquivo é formado pelo vestígio de vidas que só foram contadas em razão da existência de um fato social perturbador. Ele nasceu do encontro das pessoas com o poder, a partir da desordem provocada pelo crime. As testemunhas, as vítimas e os réus foram interpelados por um poder que vigia e reprime para explicar como aquilo pode acontecer. O que o arquivo registra é o que esse poder decidiu selecionar. Assim, o arquivo não fala a verdade, ele fala da verdade (FARGE, 2009). Dessa forma, os discursos das práticas judiciárias presentes nos processos permitem conhecer como foi produzida a verdade do arquivo (FOUCAULT, 2009). 
$\mathrm{O}$ arquivo em estudo possibilitava entender como a engrenagem punitiva se movia para produzir a verdade dos feminicídios cometidos por agressores específicos. A pergunta de pesquisa que guiou a minha análise foi: como foi produzida a verdade dos feminicídios quando cometidos por agentes de segurança e defesa do Estado? Nesse sentido, busquei identificar se a engrenagem punitiva tratava de forma mais benéfica os agressores.

Assim, o objetivo da pesquisa foi problematizar como a engrenagem punitiva produziu a verdade dos feminicídios, a partir da análise dos processos judiciais de feminicídios cometidos por agentes da segurança e defesa do Estado, no Distrito Federal, pelo período de 2006 a 2011. A verdade é entendida não pela exatidão dos fatos ocorridos, mas pela forma como os poderessaberes das práticas judiciárias penais construíram, articularam e reconheceram os feminicídios em estudo. $^{8}$

Esta é uma pesquisa qualitativa, formada por amostra representativa de casos de feminicídios cometidos por agressores que eram agentes da segurança e defesa do Estado e que ocorreram no Distrito Federal. Não se trata de pesquisa capaz de promover afirmações generalizáveis sobre o fenômeno em estudo, e sim de número pequeno de processos analisados e da realidade localizada do Distrito Federal. Isso não significa que os casos selecionados não podem trazer contribuições sobre o tema e nem ser objeto de estudo, ao contrário, a análise dos processos como parte de um arquivo permite conhecer como os poderes- saberes das práticas judiciárias penais produziram a verdade dos feminicídios e conhecer o funcionamento da engrenagem punitiva nesses casos. Além disso, estudos qualitativos como este, em um campo ainda incipiente de estudos, permitem o surgimento de novas inquietações para que futuras pesquisas sejam realizadas.

\subsection{RECONHECENDO LOCALIZAÇÕES}

Robert Yin (2016) explica que a pesquisa qualitativa, mais do que realista, é relativista, uma vez que possibilita uma multiplicidade de interpretações sobre o mesmo evento. A escolha sobre qual interpretação dar cabe a cada pesquisadora, que por meio da sua lente pessoal realizará

\footnotetext{
8 Tal enfoque se aproxima do estudo realizado por Vanessa Canabarro Dios (2016) que, na tese apresentada ao Programa de Pós-Graduação em Ciências da Saúde da Universidade de Brasília, pesquisou sobre como se constrói a verdade do estupro pelos serviços de aborto legal para que a mulher seja reconhecida como vítima de violência sexual e tenha acesso ao aborto permitido por lei no Brasil.
} 
a pesquisa. No caso, a interpretação dos dados foi realizada a partir da minha perspectiva de pesquisadora feminista?.

O estudo da violência doméstica e familiar contra as mulheres é para mim o encontro entre a militante feminista, que quer pensar formas de enfrentar a violência, e a acadêmica, que se preocupa em produzir uma pesquisa confiável. A impossibilidade de uma posição de neutralidade na ciência me dá clareza que a aproximação entre pensamento acadêmico e militância não é só possível, como necessária. (DINIZ, 2015b). O posicionamento político não inviabiliza a objetividade ou confiabilidade da pesquisa, ao contrário, é na pesquisa engajada que quero ser reconhecida como escritora confiável, apresentando um estudo que possa ser relevante às mulheres em suas lutas contra a violência.

Para Edward Said (2005), a intelectual tem um papel público na sociedade, não deve apenas reproduzir uma razão escolástica de uma casta privilegiada (BOURDIEU, 2001). Em suas palavras, a intelectual tem " vocação para representar, dar corpo e articular uma mensagem, um ponto de vista, uma atitude, filosofia ou opinião para (e também por) um público” (p. 25). É alguém que defende a liberdade e a justiça daquelas que não conseguem ser escutadas, que recusa fórmulas fáceis, clichês prontos, que não se alinha ao lado dos poderosos ou convencionais. É alguém que se dedica a ter senso crítico. Por isso, o trabalho intelectual não é simples, "envolve, ao mesmo tempo, compromisso e risco, ousadia e vulnerabilidade" (p. 31).

A intelectual de Said assume posições políticas sobre o que diz do real e não se esconde na ilusão da imparcialidade e da neutralidade da ciência. Mas, na presente pesquisa, como falar sobre violência e opressão de mulheres, e fazer uma pesquisa engajada com compromissos feministas, ocupando o lugar privilegiado da intelectual acadêmica? A ideia de que esse seria um lugar de autoridade legítima para produzir estudos sobre outras já se mostrou problemático (ALCOFF, 1991). Ainda, não há nenhuma essencialidade que unifique quem foi sexada como mulher para que a experiência me legitime a falar sobre todas ou qualquer uma (DINIZ, 2015a). A controvérsia é: falar sobre aquelas que estão em posição de maior vulnerabilidade pode significar a manutenção de uma hierarquia, mas emudecer perante a violência como forma de respeito também pode contribuir para a manutenção da subalternização das mulheres (ALCOFF, 1991).

A prática de falar sobre outras é criticada e muitas vezes até rejeitada, sob a ideia de que falar sobre alguém que não sobre si mesma, seria uma atitude arrogante, antiética e até

\footnotetext{
${ }^{9}$ Por coerência ao meu posicionamento feminista, usarei o feminino universal para me referir ao lugar de pesquisadora acadêmica.
} 
politicamente ilegítima. Nesse sentido, a autoridade para falar estaria restrita à própria experiência da falante, na sua localização social. O problema de falar sobre outras é complexo, mas pode ser resumido em dois pontos principais. O primeiro, no reconhecimento de que não transcendemos as nossas localizações pessoais quando falamos, e isso afeta o sentido e a verdade sobre o que é dito. O segundo, pelo reconhecimento de que pessoas privilegiadas falando sobre ou em benefício de grupos menos privilegiados correm o risco de serem opressoras (ALCOFF, 1991).

A localização de quem fala tem um impacto epistêmico e nem todas as localizações possuem o mesmo poder. Enquanto alguns grupos têm suas vozes silenciadas e desautorizadas, as acadêmicas, como eu, ocupam um lugar privilegiado para a verdade do dito. A escolha sobre falar ou não falar deve ser bem avaliada em cada caso, pois se falar é um risco, não falar pode ser desresponsabilizador. Por isso, é importante ter clareza das localizações, dos rituais de fala, não para restringir que se fale apenas de si mesma - pois é uma ilusão achar que não afetamos umas às outras - ou, então, para desnudar-se de forma narcisista, mas para ter clareza que falar é uma escolha que envolve responsabilidade e prestação de contas (ALCOFF, 1991).

Para falar sobre feminicídios, assumo os compromissos políticos feministas, da busca pela igualdade das mulheres. Para isso, utilizo a linguagem feminista sobre gênero e patriarcado para compreender os feminicídios e a precarização da vida das mulheres (DINIZ et al, 2015).

\subsection{NOMEAR O MARCO DE PODER}

Feminicídio é palavra recente no vocabulário do direito penal brasileiro. Em 2015, com a Lei 13.104, foi incluída como uma das hipóteses de qualificadora de homicídios para designar as mortes de mulheres pela condição de sexo feminino. ${ }^{10}$ Já no vocabulário dos movimentos feministas e de mulheres falar nos assassinatos de mulheres, seja sob a nomeação de femicídio ou feminicídio não é tema novo, ainda que atual. ${ }^{11}$

\footnotetext{
10" Feminicídio

VI - contra a mulher por razões da condição de sexo feminino:

$\mathbb{\$} 2^{\circ}-A$ Considera-se que há razões de condição de sexo feminino quando o crime envolve:

I - violência doméstica e familiar;

II - menosprezo ou discriminação à condição de mulher" (BRASIL, 1940).

11 Os estudos em geral usam as duas categorias - femicídio e feminicídio - indistintamente, sem se preocupar com as diferenças teóricas. Wania Pasinato (2011) argumenta que a falta de clareza das diferenças entre os dois conceitos prejudica o desenvolvimento de uma formulação mais política para cada um.
} 
A primeira utilização do termo, é atribuída a Diana Russel, pesquisadora feminista sulafricana, que na década de 1970 teria utilizado o termo femicídio durante depoimento perante o Tribunal Internacional de Crimes contra Mulheres, em Bruxelas (PASINATO, 2011). Em texto posterior publicado com Jane Caputi, femicídio é definido como o final extremo de um continuum de terror antifeminino, que incluiria práticas como abuso físico e verbal, estupro, incesto, agressões físicas e emocionais, mutilação genital, entre outras condutas violentas motivadas pelo ódio, desprezo, prazer ou sentimento de posse pelas mulheres. Quando o resultado dessas violências fosse a morte das mulheres, poderíamos falar em femicídio. Com o termo femicídio seria possível tirar da obscuridade o gênero escondido dos termos neutros homicídio e assassinato (RUSSEL; CAPUTI, 1992).

Já nos anos 2000, Marcela Lagarde, antropóloga mexicana, levou em conta o conceito de Diana Russel e Jane Caputi para entender o que se passava em Ciudad Juárez, no México. Desde a década de 1990, inúmeros assassinatos de mulheres e meninas passaram a ocorrer em Ciudad Juárez, marcados por desaparecimentos, tortura, violência sexual e crueldade. Ao cenário de horror somava-se a impunidade dos crimes pelas autoridades locais. Diante disso, Marcela Lagarde (2008) sustentou que o termo femicídio, homólogo a homicídio, significaria apenas assassinatos de mulheres e seria uma categoria insuficiente para evidenciar as especificidades das mortes de Ciudad Juárez. Por isso, preferiu utilizar feminicídio para se adequar ao contexto da região e denominar o conjunto de violações dos direitos humanos das mulheres, incorporando ainda ao conceito a omissão e negligência do Estado em enfrentar a violência.

A utilização das categorias femicídio e feminicídio nas diversas legislações que tipificaram as mortes de mulheres não tem seguido essa genealogia conceitual. Femicídio ou feminicídio apareceram de forma ampla e com variações de conteúdo e formato em diversos países, como: violência íntima, não íntima, sexual, como tipo penal autônomo, qualificadora ou agravante (VÍLCHEZ, 2008). No presente trabalho, me aproximarei do termo feminicídio para nomear as mortes de mulheres por violência doméstica e familiar, porque acredito que ao nomeá-las, estas mortes ganham inteligibilidade (DINIZ, et al, 2015). Nomear as mortes de mulheres por violência doméstica e familiar como feminicídio expõe o marco político das mortes, o patriarcado. Esse não é um marco neutro sexualmente, o patriarcado é o poder que subalterniza mulheres em diferentes regimes políticos, como gênero, cor, classe e colonialidade (DINIZ et al, 2015). A interseccionalidade dos diferentes regimes adiciona camadas de precarização à vida daquelas sexadas como mulheres. 
A sexagem original dos corpos em machos e fêmeas é o que inscreve sentido a matéria e conforma as formas de viver a vida pela ilusão da natureza e do destino biológico. Nem mulheres, nem homens são um grupo natural ou biológico, não há uma essência que os unifique em um binarismo sexual. Nesse sentido, gênero é o regime político que normatiza os corpos sexados, organizando as formas de vivência de cada um e criando hierarquias entre eles (DINIZ, 2015). Assim, ser sexada como mulher significa estar submetida a uma vida precarizada pelo gênero e com possibilidades de existência pré -determinadas. Gênero, como regime político, é forma de organizar a vida, é norma "de formação e conformação dos corpos sexados", mas também é o que molda as formas de convivência dos espaços sociais, como casas, escolas e delegacias (DINIZ; VIEIRA, 2017, p. 13).

Dessa forma, entendo a categoria feminicídio como a morte "de corpos sexados como mulheres pelo regime político do gênero em um marco patriarcal de poder" (DINIZ et al, 2015, p. 228). Nomear as mortes de mulheres como feminicídio não significa apenas mudança semântica com relação ao termo genérico homicídio; significa bem mais, é forma de apreensão das mortes de mulheres ocorridas em um marco de poder específico, que subalterniza os corpos sexados como femininos (DINIZ et al, 2015). Nomear feminicídio é evidenciar o patriarcado e o regime do gênero nas mortes de mulheres ocorridas por seus maridos, companheiros e ex- afetos, ou seja, é refletir "no corpo da linguagem" o que se passa no "corpo do mundo" (DAS, 2008, p. 146 - tradução livre).

Ao escolher escrever sobre feminicídio, assumo o desafio e o risco de falar sobre a experiência de mulheres variadas, vítimas de seus maridos, companheiros e ex- parceiros, que morreram de mortes evitáveis se o gênero não fosse um governo da vida violento e o patriarcado um marco de poder (DINIZ et al, 2015). Espero como uma acadêmica engajada com os compromissos políticos feministas aproveitar o meu privilégio de fala para promover a liberdade e o conhecimento (SAID, 2005), tendo em vista a minha responsabilidade e o dever de prestação de contas com o que escrevo (ALCOFF, 1991).

\subsection{CuIDADOS Éticos}

Esta é uma pesquisa documental realizada em processos judicias. A regra existente na Constituição Federal e no Código de Processo Civil é a da publicidade de todos os julgamentos e 
atos processuais do poder judiciário, com exceção dos casos em segredo de justiça. ${ }^{12}$ A Lei de acesso à informação (Lei n. 12.527/2011) reforça o entendimento da publicidade como regra e do sigilo como exceção para as informações produzidas por órgãos do Estado. Assim, processos judiciais são, em regra, documentos públicos. O projeto de pesquisa guarda-chuva da Anis, que deu início ao mapeamento dos homicídios de mulheres no DF (ANIS, 2013), foi revisado e aprovado quanto aos seus aspectos éticos pelo Comitê de Ética em Pesquisa do Instituto de Ciências Humanas (CEP-IH) da UnB. A pesquisa da Anis observou as determinações da Resolução CNS 466/2012, que dispõe sobre as diretrizes e normas regulamentadoras de pesquisas envolvendo seres humanos, e garantiu o anonimato, o sigilo e a confidencialidade dos dados dos sujeitos envolvidos nos processos.

$\mathrm{Na}$ realização da presente pesquisa também foram observados os cuidados éticos dispostos na Resolução CNS 466/2012 e no parecer do CEP/ IH. A resolução determina a observância de "procedimentos que assegurem a confidencialidade e a privacidade, a proteção da imagem e a não estigmatização dos participantes da pesquisa". Na resolução, a confidencialidade tem papel central para a eticidade das pesquisas e a sua garantia requer que sejam ocultadas informações pessoais que identifiquem os indivíduos. Isso é realizado especialmente pelo dispositivo da anonimização (DINIZ, 2015c). Embora a confidencialidade seja uma garantia importante de proteção dos sujeitos envolvidos na pesquisa e de eticidade da mesma, ela não deve ser vista como uma regra absoluta para toda e qualquer pesquisa. Nem sempre anonimizar garante a proteção, ao contrário, a nomeação dos sujeitos de pesquisa pode ser um ato de responsabilidade da pesquisadora, especialmente quando se trata de populações vulneráveis e de cenários de violações de direitos humanos (DINIZ, 2015c). Assim, em cada pesquisa deve ser avaliada a necessidade quanto a nomeação ou não dos sujeitos.

\footnotetext{
12 “Art. 93. Lei complementar, de iniciativa do Supremo Tribunal Federal, disporá sobre o Estatuto da Magistratura, observados os seguintes princípios:

(...)

IX - todos os julgamentos dos órgãos do Poder Judiciário serão públicos, e fundamentadas todas as decisões, sob pena de nulidade, podendo a lei limitar a presença, em determinados atos, às próprias partes e a seus advogados, ou somente a estes, em casos nos quais a preservação do direito à intimidade do interessado no sigilo não prejudique o interesse público à informação;” (BRASIL, 1988).

“Art. 189. Os atos processuais são públicos, todavia tramitam em segredo de justiça os processos:

I - em que o exija o interesse público ou social;

II - que versem sobre casamento, separação de corpos, divórcio, separação, união estável, filiação, alimentos e guarda de crianças e adolescentes;

III - em que constem dados protegidos pelo direito constitucional à intimidade;

IV - que versem sobre arbitragem, inclusive sobre cumprimento de carta arbitral, desde que a confidencialidade estipulada na arbitragem seja comprovada perante o juízo.” (BRASIL, 2015).
} 
$\mathrm{Na}$ presente pesquisa, a confidencialidade dos sujeitos envolvidos se justifica pelo próprio objetivo do estudo. Como o intuito é pensar a produção da verdade pelas práticas judiciárias penais não considerei necessário singularizar os acontecimentos em pessoas. Dessa forma, os envolvidos em cada processo foram anonimizados e algumas informações pessoais foram suprimidas para garantir a não identificação. Para as vítimas e agressores, os nomes foram substituídos por outros tirados de casos semelhantes e que foram noticiados pela mídia. As histórias de feminicídios analisadas não destoam das que diariamente encontramos nos jornais e noticiários nacionais, assim a troca de nomes nos casos não alterou biografias (DINIZ, 2015d). Para os atores judiciais de cada processo, também foi garantida a anonimização. Quando foi necessário fazer referência a algum deles, me referi ao nome de seus cargos - policial, delegado, juiz, Ministério Público, advogado de defesa. 


\section{CAPÍTUlO 2 - AS PRÁTICAS JUDICIÁRIAS PENAIS E A VIOLÊNCIA DOMÉSTICA E FAMILIAR}

A entrada da violência contra a mulher e, em especial, da violência doméstica e familiar, como problema do Estado tem como marco inicial a década de 1970. As mulheres e especialmente o movimento feminista passaram a denunciar a violência vivida na casa, bem como a impunidade no tratamento dos agressores nos casos que chegavam ao judiciário. Elas questionavam o entendimento de que a violência contra as mulheres era um tema circunscrito ao âmbito privado, e queriam a sua visibilidade como problema social que necessitava da interferência do estado. Os assassinatos de mulheres por seus maridos, companheiros e ex- parceiros deram impulso para a resistência feminista contra a violência. Além da luta pelo direito à sobrevivência das mulheres ao poder de vida e morte dos homens, denunciava-se o gênero no direito (MACHADO, 2002).

A legislação brasileira possuiu inúmeros dispositivos discriminatórios contra as mulheres e no que se refere aos homicídios não é diferente. ${ }^{13}$ No Brasil colônia, a lei portuguesa autorizava ao homem matar a mulher em caso de adultério. Já o contrário, não era permitido. $\mathrm{O}$ Código de 1830, o primeiro do Brasil, eliminou essa regra. O Código seguinte, de 1890, previa que o homicídio praticado sob o estado de total perturbação dos sentidos e da inteligência não era crime. ${ }^{14}$ Essa previsão legislativa possibilitava que o marido que assassinasse a esposa em situações envolvendo traição ou o desejo de separação por parte da mulher não fosse responsabilizado pelo seu assassinato, sob a alegação de que estaria experimentando um estado emocional de insanidade momentânea. Esses crimes eram conhecidos como passionais e, por isso, os homens não deveriam ser responsabilizados pelos seus atos e nem sofrer condenação criminal (ELUF, 2007).

O Código Penal de 1940, ainda em vigor, não incorporou a excludente de ilicitude do art. 27, $\sqrt{ } 4^{\circ}$ do Código Penal de 1890, que permitia a impunidade dos assassinatos ditos passionais, mas incluiu a previsão do homicídio privilegiado, que prevê a diminuição da pena para os casos em que o agente é "impelido por motivo de relevante valor social ou moral, ou sob o domínio de violenta emoção, logo em seguida a injusta provocação da vítima” (BRASIL, 1940). Não é mais autorizado pela lei que o crime considerado passional fique impune, ainda que a pena aplicada possa ser diminuída. Para seguir com a absolvição dos feminicídios, surgiu nos tribunais a tese da

\footnotetext{
13 Valéria Pandjiarjian (2006) enumera diversos dispositivos discriminatórios que vigoraram no nosso ordenamento jurídico. Entre eles, o Código Civil de 1917, estabelecia a chefia masculina na sociedade conjugal e diferenciava mulheres entre honestas e desonestas. Já o Código Penal de 1940, previa que nos crimes sexuais haveria a extinção da punibilidade quando o agente se casasse com a vítima. Além disso, o crime de posse sexual mediante fraude, atentado ao pudor mediante fraude, rapto violento mediante fraude, eram cometidos apenas contra mulher honesta.

14 Art. 27. Não são criminosos:

(...)

$\int 4^{\circ}$ Os que se acharem em estado de completa privação de sentidos e de intelligencia no acto de commetter o crime; (BRASIL, 1890).
} 
legítima defesa da honra, utilizada para a defesa de maridos, companheiros, namorados, irmãos, pais, ex- parceiros que mataram ou agrediram suas esposas, companheiras, namoradas, irmãs, filhas, ex-parceiras sob a justificativa da defesa da honra da família ou da honra conjugal. Tal tese foi objeto de luta e resistência feminista, pois implicava na impunidade de vários agressores ou na redução da pena aplicada.

Na década de 1980, surgiram campanhas contra a utilização da legítima defesa da honra como tese para a justificativa das mortes de mulheres por violência doméstica e familiar. Era por meio dessa estratégia que a defesa conseguia que agressores, mesmo confessos, não fossem devidamente punidos pelos tribunais do júri, como ocorreu no famoso caso de Doca Street, assassino de Ângela Diniz. O movimento utilizava em suas campanhas contra a violência slogans como "Quem ama não mata" e "Denuncie a violência contra a mulher". Nesse período é criado o SOS Mulher, entidade para atendimento assistencial, psicológico e jurídico às vítimas de violência (DINIZ, 2006).

Em estudo pioneiro sobre assassinatos de mulheres, Marisa Corrêa (1983) analisou os discursos das práticas judiciárias sobre os julgamentos pelo tribunal do júri de homicídios entre casais em um relacionamento amoroso. A pesquisa foi realizada em processos judiciais de homicídios e tentativa de homicídio que ocorreram em Campinas no período de 1952 a 1972. A partir do entendimento do processo como fábula, ${ }^{15}$ Corrêa observou que nos julgamentos a conduta criminosa poderia ser considerada legítima se o acusado ou acusada conseguisse provar que a quebra da norma jurídica era justificada pela defesa de normas sociais consideradas relevantes. Ou seja, a quebra da norma legal sobre não matar poderia levar a punição mais leve ou a absolvição do agressor se fosse possível mostrar que a conduta criminosa era justificada diante do desvio da vítima às normas que definem as performances de homens e mulheres em uma relação amorosa. Nos homicídios de mulheres, isso significava a utilização de teses como a legítima defesa da honra ou uso da violenta emoção para argumentar que o desajuste das mulheres diante das normas do gênero, definidas em função de sua sexagem, como mães e esposas fiéis, legitimava a conduta violenta do marido, pois significava a correção desses desvios.

\footnotetext{
${ }^{15} \mathrm{O}$ uso da categoria fábula expressa o nível simbólico dos processos judiciais, compostos por "discursos que expressam uma ordenação da realidade". Ao falar em fábula, Corrêa (1983) quer enfatizar a ideia de que "os fatos estão suspensos, de que não há mais a possibilidade de, através do processo, revivê-los". Pelos processos é possível, acessar a "conjunção de múltiplas versões, todas elas originadas pelo mesmo ato, irrecuperável" (p. 26). De forma próxima, me inspiro em Foucault (2009) para analisar os processos a partir da produção da verdade dos feminicídios pela engrenagem punitiva.
} 
Danielle Ardaillon e Guita Debert (1987) chegaram a conclusão semelhante quando analisaram processos judiciais de espancamento, estupro e assassinato de mulheres, ocorridos no período de 1981 a 1986, em seis capitais brasileiras - São Paulo, Rio de Janeiro, Belo Horizonte, Goiânia, Recife e Maceió. Elas argumentaram que nos processos judiciais não era o crime em si o que era analisado, mas os indivíduos envolvidos. Assim, a adequação às normas do gênero atribuídas aos homens e às mulheres seria o que definiria a condenação ou absolvição dos acusados. A punição estaria relacionada a conduta social do acusado e da vítima e não ao crime cometido. Nos feminicídios, o homem poderia ser absolvido se a defesa convencesse os jurados de que o acusado era pai de família, trabalhador e dedicado, e a vítima não cumpria com as obrigações de esposa e mãe.

Em momento posterior, Silvia Pimentel, Valéria Pandjiarjian, Juliana Beloque (2006) realizaram pesquisa qualitativa, em que analisaram 55 decisões dos tribunais brasileiros sobre o uso da "legítima defesa da honra", no período de 1998 e 2003, e que estavam disponíveis nas principais revistas de jurisprudência e sites dos Tribunais brasileiros. Elas constataram que apesar de estarem em menor número nos discursos judiciários, a tese da legítima defesa da honra ainda não havia sido superada e seguia sendo sustentada em todas as regiões do país. Enquanto a maioria das decisões entendeu pelo não acolhimento da tese, por entendê-la incompatível com o atual cenário jurídico brasileiro, em 03 decisões a tese foi aceita e em 14 não foi acolhida apenas por questões formais. Ou seja, nestes últimos as decisões judiciais não afirmaram a ilegalidade da tese em abstrato. As autoras concluíram que ainda haveria relutância em eliminar por completo a utilização da tese jurídica da legítima defesa da honra pelo judiciário brasileiro.

\subsection{DELEgaCias ESPECIALIZADAS}

Em 1985, foi criada a primeira Delegacia Especializada de Atendimento à Mulher (DEAM), primeiro em São Paulo, e em seguida em todo país. ${ }^{16}$ As delegacias especializadas foram celebradas como uma conquista importante do movimento feminista e de mulheres, pois responsabilizavam o Estado pelo controle da violência (BANDEIRA, 2009) e representavam uma resposta mais vigorosa aos crimes contra a mulher (SPM, 2010). O Estado foi chamado a atuar no enfrentamento a violência e a polícia foi a autoridade encarregada do primeiro contato entre o sistema de justiça e as vítimas. As DEAMs representavam a ruptura com o entendimento que

${ }^{16}$ No estado de São Paulo essas delegacias são denominadas Delegacias de Defesa da Mulher - DDM. 
“entre briga de marido e mulher, ninguém mete a colher", para o de que a violência é um problema social e o seu controle é questão de interesse público (MUNIZ, 1996; NOBRE; BARREIRA, 2008; BANDEIRA, 2009). Além disso, a partir delas, ganhou força na agenda feminista a demanda pela criminalização da violência (DEBERT; OLIVEIRA, 2007; SANTOS, 2008).

Essas delegacias especializadas são unidades da polícia civil, órgão integrante do Sistema de Segurança Pública de cada estado, que se diferenciam pelo público atendido, composto por mulheres vítimas de violência de gênero (SPM, 2010). As suas funções são comuns a qualquer outra unidade da polícia civil: o exercício de polícia judiciária e a apuração de infrações penais. ${ }^{17}$ Ou seja, devem registrar a ocorrência, conduzir o inquérito policial, colher provas e testemunhos para a instrução criminal. Dessa forma, fornecem os elementos necessários para a instauração da ação penal e da repressão aos crimes. A norma técnica de padronização das delegacias especializadas de atendimento às mulheres, da Secretaria de Políticas para Mulheres, acrescenta que as DEAMS representam um espaço de "garantia de direitos e do acesso à justiça", por serem o primeiro lugar de acolhimento das mulheres para queixas e denúncias (SPM, 2010).

Inicialmente, as delegacias especializadas deveriam ser compostas por corpo de agentes apenas de mulheres e com a integração do atendimento policial com psicossocial. A proposta era disponibilizar às mulheres atendimento integral, de forma que as vítimas conseguissem sair da relação violenta. Dessa forma, a criminalização da violência não deveria ser a única resposta para o enfrentamento a violência doméstica. Mas, como as políticas de segurança pública são definidas por cada estado, as DEAMS não possuem um modelo único de funcionamento. As diferenças estão nos tipos de atendimento disponíveis, se apenas policial ou também psicológico e social; tipo de intervenção policial, uma vez que em algumas unidades além do trabalho investigatório, os policiais atuam na mediação de conflitos e conciliação; e nos tipos de crimes atendidos, já que em algumas apenas são atendidos crimes violência doméstica e familiar e em outras não importa a relação entre agressor e vítima (PASINATO, 2010).

Estudos dedicados às delegacias especializadas relatam que desde o seu surgimento, as DEAMS não eram espaços exclusivamente voltados para o registro, investigação e repressão de crimes contra a mulher; eram também espaços de escuta, orientação e aconselhamento de vítimas e agressores. Não é incomum encontrar nos estudos relatos da existência de conciliação, negociação e mediação dos conflitos privados dentro dessas instituições. Essas práticas extra-policiais, que

\footnotetext{
17 “Art. 144 (...)

$\int 4^{\circ}$ Às polícias civis, dirigidas por delegados de polícia de carreira, incumbem, ressalvada a competência da União, as funções de polícia judiciária e a apuração de infrações penais, exceto as militares. (BRASIL, 1988).
} 
fogem da competência legalmente determinada para a segurança pública, seriam justificadas pelo desejo das mulheres em interromperem práticas de violência sem a criminalização dos agressores. Algumas vítimas queriam apenas "dar um susto" nos companheiros agressivos e não a sua prisão (NOBRE; BARREIRA, 2008; MACHADO, 2002; MUNIZ, 1996; DEBERT; OLIVEIRA, 2007).

Não há consenso dentro do movimento feminista sobre a atuação das DEAMs como espaço informal de resolução de conflitos nos casos de violência doméstica. Por um lado, a atuação informal da polícia seria legítima, já que traria o conflito para a esfera pública levando em conta os interesses das partes envolvidas e respeitando a vontade das vítimas de não punirem seus agressores (MUNIZ, 1996). Por outro, seriam práticas a margem da legalidade e que esconderiam por trás da decisão consensuada "O efeito da autoridade da agente na produção de uma verdade, à qual a denunciante adere” (MACHADO, 2002, p. 15). Os estudos das delegacias identificam uma tensão entre tratar a violência como uma questão social, que deveria ser resolvida informalmente na delegacia, ou criminal, com a abertura do inquérito policial. Para os policiais, essas atividades informais eram vistas como trabalho de pouco prestígio ${ }^{18}$ (MACHADO, 2002; DEBERT; OLIVEIRA, 2007).

\subsection{LEI N ${ }^{\circ} 9.099 / 95$}

Uma importante alteração no tratamento dado a violência doméstica e familiar ocorreu com o surgimento da Lei 9.099, de 26 de setembro de 1995, que implementou os Juizados Especiais Criminais (JECRIMs) no território nacional, em atenção ao disposto no art. 98, I, da Constituição Federal. ${ }^{19}$ Orientados por princípios como a oralidade, informalidade, economia processual e celeridade, esses juizados deveriam buscar a reparação dos danos sofridos pelas vítimas e a utilização de penas diversas da privativa de liberdade. Essa lei inaugurou um sistema de justiça penal consensual, uma vez que retirou a obrigatoriedade da instauração da ação penal e da pena privativa de liberdade (GRINOVER et al, 2005). Aos crimes de menor potencial ofensivo, definidos no art. 61 como as contravenções penais e os crimes com pena máxima não superior a

\footnotetext{
18 Saffioti (2002, p. 67) afirma que as DEAMS eram vistas pelos policiais como a "cozinha da polícia".

19 “Art. 98. A União, no Distrito Federal e nos Territórios, e os Estados criarão:

I - juizados especiais, providos por juízes togados, ou togados e leigos, competentes para a conciliação, o julgamento e a execução de causas cíveis de menor complexidade e infrações penais de menor potencial ofensivo, mediante os procedimentos oral e sumaríssimo, permitidos, nas hipóteses previstas em lei, a transação e o julgamento de recursos por turmas de juízes de primeiro grau"(BRASIL, 1988).
} 
dois anos, cumulada ou não com multa, ${ }^{20}$ poderiam ser aplicados um dos três institutos despenalizadores: a composição civil dos danos, a transação penal ou a suspensão condicional do processo. Outras inovações implementadas foram a necessidade de representação da vítima nos casos de lesão corporal leve e culposa, e a substituição do inquérito policial pelo termo circunstanciado.

A Lei 9.099/95 foi criada com a finalidade de dar tratamento menos rigoroso aos crimes de pouca repercussão social e de baixa lesividade, o que permitiria desafogar a justiça e presídios, além de evitar os efeitos estigmatizadores do encarceramento para os etiquetados como criminosos. A previsão da utilização dos institutos despenalizadores e desencarceradores significou a recepção do paradigma da mínima intervenção penal e, por isso, foi celebrada como uma vitória do movimento criminológico. A Lei seria um passo em direção a redução do precarizado sistema punitivo clássico, centrado na pena de prisão.

A expectativa original era de que os juizados se dedicassem aos crimes eventuais, como os de trânsito e os pequenos furtos, mas, na prática, grande parte dos crimes compreendidos pelos JECRIMs foram de violência doméstica e familiar contra a mulher. Carmen Campos e Salo de Carvalho (2006) relataram que 60\% a 70\% do volume processual dos JECrims era composto de crimes de ameaça e de lesões corporais cometidos contra as mulheres. Parte do movimento feminista criticou intensamente a entrada dos crimes de violência doméstica na competência dos juizados. Entre os principais argumentos estaria a classificação dos crimes como de menor potencial ofensivo, tendo por critério a pena cominada em abstrato ao delito. Ao considerar a violência doméstica como delito não grave, a lei teria banalizado a violência, por desconsiderar as suas especificidades, como a habitualidade, a assimetria de poder entre agressor e vítima, a escalada violenta e o verdadeiro potencial ofensivo dos crimes (CAMPOS, 2003; CAMPOS; CARVALHO, 2006; BANDEIRA, 2008; PANDJIARJIAN, 2006).

O novo procedimento, modificou a atuação das delegacias para os crimes de menor potencial ofensivo, pois houve a substituição do inquérito pelo termo circunstanciado. Dessa forma, após a declaração da ocorrência da vítima, o termo era imediatamente remetido ao poder judiciário, acompanhado de laudo pericial, nos casos em que este era necessário. Não havia oitiva de testemunhas e nem do autor do fato. As delegacias perderam assim parte do seu papel investigatório com a retirada do inquérito policial dos crimes mais recorrentes (SANTOS, 2008;

\footnotetext{
20 Inicialmente os crimes de menor potencial ofensivo eram aqueles com pena menor ou igual a um ano. A Lei $n^{\circ}$ 11.313/2006 alterou a redação para que a pena passasse a ser de no máximo dois anos.
} 
SAFFIOTI, 2002). A mudança no funcionamento das delegacias evitou que as práticas de conciliação e arquivamento de casos continuassem a ocorrer por meio da autoridade policial, mas não significou o seu fim. O arquivamento dos processos passou a ocorrer pelo próprio judiciário, que, segundo Carmen Hein de Campos (2003), atuava na indução a renúncia da representação das vítimas, a partir do compromisso do agressor de não cometer mais o ato violento.

A crítica aos juizados foi no sentido de que os poucos casos em que não havia renúncia e que chegavam a fase de transação penal o desfecho dos crimes consistia no pagamento de multas ou de cestas básicas pelos agressores. Isso não significava benefícios para as vítimas, nem materiais e nem quanto à garantia de viver uma vida sem violência (CAMPOS, 2003). Muitas feministas se posicionaram contra a conciliação que ocorria nos JECRIMs porque, diferente das DEAMs, onde se esperava que fossem espaços especializados para responder a violência contra a mulher, os juizados não haviam sido criados levando em conta as especificidades dessa violência. Nos juizados partia-se do pressuposto que vítima e réu seriam negociantes em posições de igualdade, não partes de um conflito violento do gênero. Além disso, a conciliação dos JECRIMs era orientada pela defesa da família, de forma que o caráter propriamente criminoso dos crimes era ignorado e o conflito devolvido à esfera privada para ser solucionado (DEBERT; OLIVEIRA, 2007).

Nessa perspectiva, a Lei 9099/95 teria sido criada para tratar de crimes eventuais, cujos envolvidos eram homens, não teria sido pensada para tratar da violência do gênero. Assim, a pretensa neutralidade da lei era desfeita pela sua aplicação prática: havia benefícios para os autores dos crimes, que escapavam dos efeitos do sistema penal, mas não proteção às vítimas de violência doméstica. A incompreensão das especificidades da violência doméstica e familiar contra a mulher e a desproteção das vítimas levaram parte do feminismo a defender que a violência estava sendo banalizada (CAMPOS, 2003; PANDJIARJIAN, 2006).

Wânia Pasinato (2003) apresentou divergência a esse entendimento. Em sua tese de doutorado, ela realizou pesquisa em três delegacias especializadas (DDMs) no município de São Paulo, onde coletou dados de amostra representativa de todos os registros policiais de violência doméstica e familiar contra a mulher do período de 1996 e 1999. Além disso, acompanhou audiências e o desfecho final de alguns casos. Pasinato constatou que, a partir da implementação dos JECRIMs, houve aumento do número de queixas registradas, o que mostrava que esses eram espaços de referência para as mulheres buscarem proteção. Em seu trabalho, ela defendeu que as medidas despenalizadoras da Lei 9.099/95 responderiam as expectativas de mulheres que desejavam cessar a violência e que denunciavam os seus agressores em busca de intervenção estatal 
sem que isso significasse o encarceramento de seus agressores. Ainda, argumentou que as mulheres que buscavam o aparato policial - judicial para interferir na relação violenta manifestavam poder, pois eram sujeitos ativos que buscavam reverter a situação que viviam. Assim, as delegacias e os Juizados seriam espaços de exercício de empoderamento para as mulheres e não de aumento de desigualdade.

Ainda que a perspectiva apresentada por Pasinato (2003) seja importante para problematizar as críticas à Lei 9.099/95, acredito que as suas conclusões devem ser vistas com cautela, já que muitas mulheres se encontram em situação fragilizada pela violência e podem ter mais dificuldades em sair do cenário da violência, como as que são dependentes econômicas do agressor e possuem filhos com ele. As críticas à Lei 9.099/95 mostraram que o ordenamento jurídico não havia reconhecido a violência do gênero e nem apresentado respostas específicas para responder a esta violência. Até aquele momento, faltava uma legislação para enfrentar a violência doméstica e familiar contra as mulheres de forma integral.

\subsection{Lei Maria da Penha (LMP)}

Em 2002, ONGs feministas, movimento de mulheres e parlamentares se organizaram em um consórcio para elaboração de uma proposta de lei integral de combate a violência doméstica e familiar, tendo por base os tratados internacionais sobre direito das mulheres, especialmente a Convenção sobre a Eliminação de Todas as Formas de Discriminação contra as Mulheres e a Convenção de Belém do Pará. Em seguida, no ano de 2004, foi criado o Grupo de Trabalho Interministerial, coordenado pela Secretaria de Políticas para Mulheres, para elaborar um projeto de lei sobre o enfrentamento à violência doméstica, que se baseou no estudo feito pelo consórcio. Houve um período de debate com a sociedade civil, e, em 07 de agosto de 2006 foi criada a Lei 11.340 (MATOS; CORTES, 2011).

A nova legislação ficou conhecida como Lei Maria da Penha como forma simbólica de reparar Maria da Penha Maia Fernandes, pela leniência da justiça brasileira na punição de seu agressor. Em 1983, o seu então marido, Marco Antonio Heredia Viveiros, tentou assassiná-la com um tiro nas costas. Embora não tenha conseguido matar a esposa, Maria da Penha ficou paraplégica. Duas semanas após essa primeira tentativa, ele tentou matá-la novamente com eletrochoques. Após esses fatos ela decidiu denunciá-lo. A morosidade da justiça brasileira fez com 
que mesmo após quinze anos dos crimes cometidos, não houvesse uma decisão final sobre o caso e o agressor seguisse em liberdade.

Em 1998 o caso foi levado à Comissão Interamericana de Direitos Humanos (CIDH) pelo o CEJIL-Brasil (Centro para a Justiça e o Direito Internacional) e o CLADEM-Brasil (Comitê Latino-americano do Caribe para a Defesa dos Direitos da Mulher), juntamente com a vítima Maria da Penha Maia Fernandes (caso Maria da Penha n. ${ }^{o}$ 12.051). Em 2001, a CIDH responsabilizou o Estado brasileiro por negligência, omissão e tolerância em relação à violência doméstica contra as mulheres, recomendando, entre outras medidas a adoção de políticas públicas voltadas a prevenção, punição e erradicação da violência contra a mulher (COMPROMISSO E ATITUDE, 2012).

A nova legislação mudou a gestão da violência doméstica e familiar, e representou um marco para o reconhecimento da violência doméstica e familiar como um crime e "é um dos dispositivos que melhor expressa o acúmulo das lutas do movimento feminista brasileiro" (FONSECA, 2012, p. 60). Na Lei Maria da Penha, a violência doméstica e familiar contra a mulher é considerada uma forma de violação aos direitos humanos, e consiste em qualquer ação ou omissão baseada no gênero que cause morte, lesão, sofrimento físico, sexual ou psicológico e dano moral ou patrimonial, no âmbito da unidade doméstica, da família ou em qualquer relação íntima de afeto às mulheres. A violência é entendida de forma ampla, e compreende a violência física, psicológica, patrimonial ou moral. A Lei não criou nenhum tipo penal novo, ela apenas definiu quais crimes poderiam ser considerados como violência doméstica e familiar (BRASIL, 2006).

As novidades da lei podem ser divididas em três eixos principais: o primeiro, compreende as medidas criminais, como a retomada do inquérito policial; a possibilidade de prisão preventiva do agressor em qualquer fase do inquérito ou instrução criminal; a inclusão de uma qualificadora nos crimes de lesão corporal, de forma que a necessidade de representação para a ação penal ficasse restringida; a proibição de utilização da Lei 9099/95 nos crimes de violência doméstica e familiar, independentemente da pena prevista; o veto a utilização de penas de cesta básica ou outras de prestação pecuniária. O segundo eixo é composto pelas medidas de proteção a integridade física e aos direitos da mulher, como as medidas protetivas de urgência para as mulheres e as que são voltadas aos agressores. Ainda, medidas de assistência, como atendimento psicológico, jurídico e social. Já o terceiro eixo é integrado por medidas de prevenção e educação a violência. Para que o enfrentamento à violência seja feito de forma integral, a Lei criou os Juizados de Violência Doméstica e Familiar contra a Mulher com competência cível e criminal, e previu políticas públicas nas áreas da segurança pública, saúde, assistência (PASINATO, 2010). 
A nova gestão da violência doméstica e familiar contra as mulheres instituída com a LMP, de certa forma, aposta na funcionalidade do direito penal para enfrentar a desigualdade do gênero (CASTILHO, 2007), uma vez que retoma os mecanismos formais de controle social, com a centralidade na privação de liberdade como punição, em razão do afastamento dos institutos despenalizadores da Lei 9099/95. ${ }^{21}$ A Lei também aumentou a punição para o crime de lesão corporal e incluiu agravante genérica para os demais crimes. Na presente pesquisa, parto da inquietação do uso do sistema de justiça criminal para as lutas por igualdade, uma vez que o sistema penal não tem se mostrado capaz de cumprir com as funções que legitimam a sua existência, como a proteção igualitária a bens jurídicos, prevenção de crimes e ressocialização. De forma contrária, o sistema tem operado na construção seletiva da criminalidade e na fabricação de criminosos. (ANDRADE, 2005).

\subsection{LEI DO FEMINICÍDIO}

Embora com a LMP a violência doméstica e familiar contra a mulher tenha sido caracterizada como crime específico, não houve menção em seus artigos aos assassinatos de mulheres pelo regime do gênero. Nesse sentido, houve novo momento importante de resistência feminista à violência: a demanda pela tipificação do feminicídio na legislação brasileira, seja como qualificadora do homicídio ou como tipo penal autônomo. Debora Diniz, Bruna Costa e Sinara Gumieri Vieira (2015) mapearam os principais discursos em torno da necessidade da tipificação do feminicídio no Brasil. As autoras identificaram que o debate sobre o tema se deu especialmente em campanhas educativas, notícias de jornal, projetos de lei e decisões judiciais, e que a principal aposta da tipificação estaria na possibilidade de melhor proteger mulheres e punir agressores. Outros desdobramentos da tipificação seriam a maior visibilidade às mortes de mulheres, que estariam escondidas no tipo penal genérico do homicídio e a possibilidade de mudança de práticas sociais violentas contra a mulher, pelo efeito simbólico do uso do direito penal. Apesar dos efeitos da criminalização na prevenção de novas condutas e proteção de bens jurídicos ser objeto de crítica, a qualificadora foi aprovada no ano de 2015.

Em 09 de março de 2015, foi publicada a Lei n ${ }^{\circ}$ 13.104, que incluiu a qualificadora do feminicídio no código penal brasileiro. A nova qualificadora definiu o feminicídio como homicídio

\footnotetext{
${ }^{21} \mathrm{Na}$ prática os institutos continuaram a ser utilizados em algumas partes do País. No relatório final da Comissão Parlamentar Mista de Inquérito (CPMI) da violência doméstica consta que em algumas capitais e no interior do País, os operadores jurídicos continuaram aplicando os institutos despenalizadores da Lei 9.099/95, em especial, a suspensão condicional do processo (SENADO FEDERAL, 2013).
} 
cometido "contra a mulher por razões da condição de sexo feminino". As razões de sexo feminino definidas na nova lei seriam: a violência doméstica e familiar e o menosprezo ou discriminação à condição de mulher. Como homicídios qualificados, os feminicídios passaram a integrar o rol dos crimes considerados hediondos. A Lei ainda incluiu como causas de aumento de crime, quando o feminicídio fosse praticado contra mulheres grávidas ou nos três meses posteriores ao parto, contra mulheres com menos de 14 anos, com mais de 60 anos ou com deficiência, e ainda quando fosse cometido na presença de ascendentes ou descendentes da vítima.

Inicialmente, no projeto elaborado pela Comissão Parlamentar Mista de Inquérito (CPMI) da violência contra a mulher, feminicídio seria definido como "forma extrema de violência de gênero que resulta na morte da mulher". Posteriormente, com os substitutivos apresentados pela Comissão de Constituição e Justiça (CCJ) e pela Procuradoria da Mulher do Senado Federal, feminicídio foi definido por morte "por razões de gênero" (CAMPOS, 2015). Na Câmara dos Deputados, feminicídio deixou de ser a morte da mulher por "razões de gênero" e foi substituída por "condição de sexo feminino". Essa mudança não é apenas terminológica, mas representa a forte resistência do Congresso Nacional ao uso da palavra gênero e à ampliação de direitos e garantias às minorias sexuais.

Isso porque o conceito de gênero tem sido distorcido por políticos religiosos e conservadores, que defendem que gênero seria uma ideologia, capaz de destruir a família tradicional brasileira, por permitir o reconhecimento da diversidade de vivência dos corpos e da sexualidade Para os críticos da categoria gênero, a "ideologia de gênero" seria perversa, pois ensinaria que cada pessoa deveria inventar um gênero para si mesma, o que deformaria a própria identidade. ${ }^{22}$ Assim, grupos religiosos têm atuado para a exclusão da palavra gênero e de discussões sobre discriminação de minorias sexuais do cenário político, como foi o caso do plano nacional de educação e, em seguida, dos diversos planos estaduais e municipais de educação.

Dentro desse cenário político, a mudança da palavra "gênero" por "sexo" na Lei do feminicídio, representa não apenas um retrocesso para o movimento feminista e de mulheres, mas é também uma interferência religiosa indevida e discriminatória. Com a supressão de gênero do texto legal, os parlamentares buscaram interferir na aplicação da lei, de forma que mulheres trans não fossem amparadas pelo dispositivo legal, já que com uso de "sexo" pretendia-se que apenas

\footnotetext{
22 A organização "Observatório Interamericano de Biopolítica" é composta por pessoas que buscam influenciar parlamentares em temas que envolvem vida, família, educação e liberdade. Em seu site, é explicado o que seria a "ideologia de gênero". Disponível em: < http://biopolitica.com.br/index.php/artigos/40-voce-ja-ouviu-falar-sobre-aideologia-de-genero>. Acesso em 06 fev. 2017.
} 
aquelas originalmente sexadas como mulheres poderiam ser vítimas de feminicídios (CAMPOS, 2015; CASTILHO, 2015).

\subsection{O ACIONAMENTO PENAL - POLICIAL}

O enfrentamento à violência doméstica percorreu um caminho longo de lutas e resistências feministas. Se em um primeiro momento, houve críticas ao uso da engrenagem punitiva, especialmente pelo descaso e impunidade no julgamento dos crimes, em um segundo, houve um apelo ao uso do braço penal do Estado para a proteção das mulheres, com novas leis e órgãos destinados a isso. A polícia esteve presente no enfrentamento à violência doméstica desde as primeiras conquistas feministas. Hoje, com a Lei Maria da Penha, ela segue ocupando um lugar de destaque: é a principal porta de entrada para as vítimas de violência buscarem proteção, acessarem seus direitos e serviços disponíveis.

A LMP trata no capitulo III “do atendimento da autoridade policial”, especificando a forma como deve se dar o encontro entre polícia e mulheres, e quais as funções esperadas do aparato policial. Vale ressaltar que com a Lei não houve interferência nas competências estabelecidas pela Constituição Federal entre as diferentes polícias e nem referência apenas a atuação das DEAMS. A polícia civil, que atua na fase pré- processual, segue com atividades de investigação do crime e de "primeira instancia de formação da culpa" e a polícia militar na atuação do policiamento ostensivo (BARBOSA; FOSCARINI, p. 251). Quanto ao atendimento às vítimas, a polícia deve garantir a proteção das mulheres, encaminhá-las a serviços médicos ou acompanhálas para retirar seus pertences da casa, fornecer o transporte para abrigo ou local seguro e informálas sobre os seus direitos e os serviços disponíveis. Feito o registro da ocorrência, deve a autoridade policial ouvir a vítima, o agressor e as testemunhas; colher as provas dos fatos; remeter em até 48 horas as medidas protetivas de urgência solicitadas; ordenar a identificação do agressor e fazer juntar aos autos a folha de antecedentes criminais; nos casos necessários, determinar a realização de exames periciais; e remeter os autos do inquérito policial ao juiz e ao Ministério Público (BRASIL, 2006).

Entre as novidades na atuação da polícia está o requerimento das medidas protetivas de urgência no curso do inquérito policial ou do processo penal, a pedido da vítima, de seu representante legal ou de ofício, que devem ser remetidas ao poder judiciário (artigo 18). Aqui não é necessário ouvir testemunhas e o autor do crime. Para a garantia da execução das medidas 
protetivas de urgência, a LMP também incluiu hipótese de decretação da prisão preventiva nos crimes dolosos de violência doméstica e familiar. A prisão preventiva do agressor também poderá ser requerida pela autoridade policial em qualquer fase do inquérito ou da instrução criminal.

As novas possibilidades de mecanismos para o enfrentamento da violência continuam no sentido de ampliação do uso do aparato penal - policial. O Projeto de Lei na Câmara n. 07 de 2016 (PLC 07/2016), proposto pelo deputado Sergio Vidigal (PDT-ES), é um exemplo disso, pois “acrescenta dispositivos à Lei $\mathrm{n}^{\circ}$ 11.340, de 7 de agosto de 2006, para dispor sobre o direito da vítima de violência doméstica de ter atendimento policial e pericial especializado, ininterrupto e prestado, preferencialmente, por servidores do sexo feminino, e dá outras providências”. Além da previsão da realização do atendimento policial de forma ininterrupta e preferencialmente por policiais mulheres, o projeto de lei prevê a inclusão do art. 12- B na LMP, para permitir nos casos de "de risco atual ou iminente à vida ou integridade física e psicológica da vítima ou de seus dependentes", a aplicação provisória de medidas protetivas de urgência pela autoridade policial. O juiz deverá ser comunicado dessa decisão no prazo de vinte e quatro horas, podendo manter ou rever as medidas aplicadas.

A medida é tida como necessária para o aumento da proteção das mulheres, pois tem como justificativa a lentidão do judiciário no deferimento das medidas protetivas. Mas, seria o aumento do poder policial a medida mais efetiva para promover a proteção das mulheres? Além disso, no projeto, não fica claro quais alternativas poderiam ser adotadas no caso de a autoridade policial não conceder o pedido de medidas protetivas de urgência.

A Lei Maria da Penha conferiu poderes importantes para a polícia na resposta à violência e é possível que esse poder ainda aumente. É na delegacia que as mulheres vão relatar abusos, buscar orientação e medidas para conter a violência sofrida. Além disso, e para o que é mais importa para o presente trabalho, a polícia é um dos agentes da engrenagem punitiva que atua na produção da verdade da violência.

\subsection{A ENGRENAGEM PUNITIVA E O PATRIARCADO}

O funcionamento da engrenagem punitiva tem sido objeto de muitas críticas, pois enquanto o sistema penal tem como função declarada a proteção igualitária de bens jurídicos, a prevenção de crimes e a ressocialização de agressores, a sua real operacionalidade tem sido outra, como as denúncias realizadas pelas criminologias críticas tem demonstrado. Sem pretender 
explorar as diferentes correntes do campo criminológico - crítico, mas apresentar algumas das contribuições que são relevantes para o presente estudo, vou utilizar o entendimento de Alessandro Baratta (2004) para reunir os diferentes discursos desse campo pelo o que apresentam em comum: uma nova forma de definir a questão criminal em comparação com a criminologia tradicional. Tendo por base o paradigma da reação social, a criminologia crítica deixou de tratar o crime a partir de uma noção ontológica e passou a se dedicar aos processos de criminalização, ou seja, a atribuição de crime a certas condutas e de criminoso a certos sujeitos numa dada sociedade. Nesse sentido, a legitimidade do sistema penal foi questionada, já que as funções que em teoria deveriam ser realizadas, na prática, não se concretizariam.

Com esse enfoque foi possível deixar em evidência muitas fragilidades do sistema penal, tais como a desigual proteção de bens e interesses, e a desigual distribuição de riscos e imunidades no processo de criminalização (BARATTA, 1999; ANDRADE, 1999). A função do sistema penal não seria “combater (reduzir e eliminar) a criminalidade, protegendo bens jurídicos, mas, ao invés, construí-la seletiva e estigmatizantemente, e neste processo reproduzir, material e ideologicamente, as desigualdades e assimetrias sociais" (ANDRADE, 2005, p. 79). Assim, o sistema penal reproduziria as desigualdades sociais, de forma que os grupos vulneráveis seriam os principais etiquetados como criminosos e os grupos dominantes os principais beneficiários dos processos de imunização.

Essa conclusão é semelhante a que Foucault (2010) chegou ao descrever os processos que levaram as transformações na arte de punir, dos suplícios a pena de prisão. O encarceramento ganhou a posição principal de técnica disciplinar do sistema penal, apesar do seu atestado fracasso na correção de infratores. Mas, esse fracasso seria apenas aparente, já que o real objetivo do castigo seria 'contribuir para estabelecer uma ilegalidade, visível, marcada, irredutível a um certo nível e secretamente útil - rebelde e dócil ao mesmo tempo; essa forma é a delinquência" (p. 262). O sistema penal não seria um instrumento para reprimir e prevenir crimes, mas sim para a gestão diferenciada das ilegalidades. A delinquência seria uma das formas de ilegalidades, mas seria aquela que o sistema deu um papel instrumental em relação as outras. A fabricação da delinquência permitiria o controle de indivíduos selecionados e a ilegalidade dos grupos dominantes. A delinquência seria efeito da penalidade, não falha na correção.

A engrenagem punitiva além de reproduzir as desigualdades de classe e raça, também atuaria na atualização das desigualdades do gênero. O alto risco do acionamento penal existiria não só para os agressores, mas também para as vítimas, uma vez que o sistema não seria capaz de 
protegê-las de novas violências e nem de alterar práticas sociais opressoras. Além disso, haveria o risco de o sistema duplicar a violência, como nos casos de violência sexual, em que a moral sexual dividiria as mulheres vítimas entre honestas e desonestas (ANDRADE, 1999). Os efeitos do uso da engrenagem punitiva devem ser levados em conta para se pensar demandas para a igualdade. As diferentes agências do sistema penal atuam para a gestão diferenciada das ilegalidades e consequente produção da delinquência. O aparelho policial é a principal porta de entrada do sistema de justiça criminal e tem um papel central na seleção dos sujeitos criminosos. É a vigilância policial que fornece os infratores que a prisão transforma em delinquentes (FOUCAULT, 2010).

Assim, é importante investigar como a polícia e os diversos atores judiciários respondem à violência doméstica e familiar contra as mulheres, ainda mais quando se trata de agressores que são seus pares. 


\section{CAPÍTUlO 3 - A VERDADE DOS FEMINICÍDIOS}

Como todos os crimes, as investigações sobre as mortes de mulheres por seus companheiros, maridos e ex- parceiros são feitas pela polícia pelo procedimento administrativo do inquérito policial, que é voltado à produção preliminar de provas, com o intuito de apurar a prática do crime e sua autoria. Esse é um procedimento inquisitivo, em que não há oportunidade de defesa. É também sigiloso, uma vez que o acesso aos autos do inquérito é possibilitado apenas ao advogado. Após encontradas as provas suficientes de autoria e materialidade do crime pela polícia, o Ministério Público oferece a denúncia. A partir disso, as provas do crime são colhidas diante do juiz togado, e respeitando o contraditório e a ampla defesa.

Após a instrução processual, o juiz decidirá se é viável ou não enviar o caso para ser apreciado pelo Tribunal do Júri ${ }^{23}$ e nesse momento poderá pronunciar o réu, impronunciá-lo, absolvê-lo sumariamente ou desclassificar a infração. ${ }^{24}$ Caso o réu seja pronunciado, é iniciada a fase de preparação do plenário, em que testemunhas irão novamente depor e novos documentos poderão ser juntados aos autos, bem como novas diligências realizadas. Ao fim do interrogatório do réu, da inquirição de testemunhas e dos debates entre Ministério Público e defesa, o Conselho de sentença, composto por jurados leigos, irá julgar o caso. Os jurados devem votar sim ou não, sem necessidade de justificação, aos quesitos apresentados sobre o desfecho do crime e a punição do agressor.

Nos feminicídios, os testemunhos de amigas e familiares da vítima e do réu serão determinantes para estabelecer a verdade pelas práticas judiciárias penais, já que permitem reatualizar no presente os fatos do passado (FOUCAULT, 2009). Giorgio Agamben (2008) diferencia dois tipos de testemunho: o primeiro, chamado testis, é aquele em que a testemunha é um terceiro e não vivenciou a experiência por si mesmo; o segundo, supertestis, a testemunha experimentou o acontecimento e pode oferecer um relato do que viveu. Didier Fassin (2008) acrescenta que o testis seria apenas um observador e a confiabilidade do seu testemunho estaria na sua suposta neutralidade. Enquanto o supertestis é um sobrevivente, a sua palavra é ouvida porque

\footnotetext{
23 De acordo com o art. 5 XXXVIII, d), da Constituição Federal, o Tribunal do Júri tem competência para o julgamento dos crimes dolosos contra a vida (BRASIL, 1988).

${ }^{24}$ A pronúncia é a decisão do juiz togado que "julga admissível a acusação, remetendo o caso à apreciação do Tribunal do Júri” (NUCCI, 2012, p. 740). Já a impronúncia, é a decisão que julga improcedente a denúncia ou queixa por não existir prova da materialidade do crime ou indícios suficientes de autoria. A desclassificação penal é a decisão que modifica a tipificação legal da denúncia (NUCCI, 2012, p. 748). Já a absolvição sumária, é a decisão que coloca fim ao processo quando: i) provada a inexistência do fato; ii) provado não ser ele autor ou partícipe do fato; iii) o fato não constituir infração penal; iv) demonstrada causa de isenção de pena ou de exclusão do crime. (NUCCI, 2012, pp. 748 - 752).
} 
ele esteve presente no evento relatado. Se a verdade do testemunho do testis é objetiva, já que se trata de alguém externo ao evento, a do supertestis é subjetiva, pois tem como base a própria experiência.

Os testemunhos dos feminicídios são de terceiros, daquelas pessoas que estiveram presentes quando ocorreu o acontecimento trágico ou que conheciam detalhes da vida da vítima e do agressor, e que poderiam contribuir para o estabelecimento da verdade, já que a vítima não sobreviveu. A partir da desordem social provocada pelo crime, as testemunhas são interpeladas a explicar como aquilo pôde acontecer e devem revelar informações que não se restrinjam apenas ao fato criminoso. Apesar de se tratar de terceiros, os testemunhos dos testis não podem se dizer neutros, o que falam é sobre aquilo que lhes foi perguntado pelos agentes da engrenagem punitiva e o que o arquivo registra dos testemunhos é o que foi selecionado pelos saberes- poderes da prática judiciária. A verdade que é construída nos autos se articula a partir de um poder que obrigou aquela narrativa.

A polícia, a defesa, o Ministério Público e o juiz são os principais responsáveis por traduzir as provas, os testemunhos e o depoimento do acusado em discursos que vão produzir a verdade. Essa verdade não está pronta, mas ela se realiza a partir do que eles entendem como justo. Assim, a escolha dos agentes da engrenagem punitiva sobre quais discursos e provas apresentar aos jurados, como argumentos da acusação e da defesa, é decisiva para a punição do agressor, mas também é reveladora do funcionamento da engrenagem punitiva.

\subsection{FEMINICÍDIOS}

\section{Caso 01}

No processo 01, Edgar, tenente da polícia militar, e Elaine, eram casados e possuíam duas filhas em comum. Além delas, residiam com o casal, uma filha, de 10 anos, e um filho, de 16 anos, de outros relacionamentos da vítima. ${ }^{25}$ No testemunho do irmão da vítima, a relação entre Edgar e Elaine era descrita como conturbada, marcada por términos e recomeços, sendo que o agressor já havia se mostrado violento em algumas ocasiões. Consta nos autos do processo de feminicídio, registro de ocorrência de violência de um ano anterior ao feminicídio, em que a vítima

\footnotetext{
${ }^{25}$ Nomes retirados da notícia: Policial militar é preso em flagrante após matar a esposa em Taboão da Serra (SP). Notícias R7, 11 jun. 2016. Disponível em: <http://noticias.r7.com/cidade-alerta/videos/policial-militar-e-preso-emflagrante-apos-matar-a-esposa-em-taboao-da-serra-sp-11062016>. Acesso em: 06 mar. 2017.
} 
relatou que o marido teria lhe agredido fisicamente, ameaçado de morte, além de ter quebrado móveis da casa. No seu testemunho, ela contou que representou contra ele na corregedoria da polícia militar, recebeu intimação para comparecer até lá, mas como recebeu ameaças de morte do marido, não deu continuidade ao procedimento.

Segundo a denúncia, no dia dos fatos, Edgar e a vítima se desentenderam por conta do conserto de um automóvel. À noite, Elaine e o filho foram à casa de uma amiga da vítima, e lá permaneceram até a madrugada do dia seguinte, sendo que as duas filhas pequenas haviam sido deixadas aos cuidados da sobrinha da vítima de 15 anos. Edgar chegou em casa por volta das 19 horas, e não se conformou com a ausência da esposa. Ligou insistentemente para que ela retornasse à casa. Quando ela e o filho finalmente chegaram, Edgar os aguardava na porta de casa com o automóvel ligado e as duas filhas menores do casal no interior do veículo. Assim que Elaine parou o carro, ele sacou a arma e efetuou disparos contra ela e contra o enteado, não atingindo o último porque a vítima protegeu o filho.

Após o crime, Edgar fugiu com as duas crianças pequenas, mas dias depois confessou a autoria do crime na delegacia. Em sua versão dos fatos, a motivação do crime seria outra, ele e a vítima teriam sim discutido sobre o reparo do carro, mas ela também o teria humilhado na noite anterior ao crime, em razão dele ter se relacionado com a cunhada dela. As duas, a vítima e a cunhada, teriam ligado para ele e o xingado de canalha e mau caráter. Na noite do crime, ele teria ficado em casa cuidando das crianças que estavam doentes e no momento em que a vítima chegou em casa, ele estaria saindo para levar as filhas ao hospital. Como havia esquecido o portão aberto, voltou para fechá-lo, quando a vítima chegou e começou a xingá-lo. Nesse momento, sacou o revólver e atirou contra ela. Não teria tentado matar o enteado, mas teria tentado o suicídio, efetuando, no entanto, um disparo acidental em sua coxa. Afirmou que estava com problemas psicológicos devido às brigas e humilhações que sofria da vítima, e que estaria fazendo uso de medicamentos controlados e estaria com restrição ao uso de arma.

Como uma das portas de entrada da violência, é na delegacia que serão produzidos os primeiros discursos de verdade da violência e o inquérito policial é o documento que "dá a primeira feição ao fato acontecido" (CORRÊA, 1982, p. 35), com a seleção das testemunhas e do que deve ou não constar como prova nos autos. No relatório composto pela autoridade policial no fim da fase de investigação do caso relatado, chegou-se à conclusão de que existiriam "contradições evidentes no que foi apurado até o momento." Além da dinâmica do próprio crime - quantos disparos teriam ocorrido, se o enteado também teria sido alvo do agressor - a autoridade policial 
considerou relevante registrar dúvidas quanto ao vício em drogas da vítima e de seu filho: "Edgar diz que o enteado e Elaine são viciados em drogas, maconha e cocaína, respectivamente. O enteado nega que ele e sua mãe sejam usuários de drogas”.

Tendo em vista a confissão do agressor e a materialidade do crime, Edgar é denunciado por homicídio duplamente qualificado, por motivo fútil, consistente na insatisfação com o relacionamento e a demora da esposa em voltar para casa, e pelo uso de recurso que impossibilitou a defesa da vítima, já que teria dissimulado a sua intenção homicida. Além disso, foi incriminado pela tentativa de homicídio do enteado.

No interrogatório do agressor, antes da decisão de pronúncia, a versão dos fatos foi modificada e o réu acrescentou detalhes sobre quem a vítima seria. Ele afirmou que no dia dos fatos, pela manhã, discutiu com a esposa porque ela queria dar a direção do carro para o enteado, o que ele discordava, já que o adolescente teria batido o veículo outras vezes e estaria envolvido com drogas. À noite, quando chegou à casa, verificou que as duas filhas estavam doentes e sendo cuidadas pela sobrinha. Ligou para a esposa para informar que as meninas estavam doentes e ela disse que estaria voltando para casa. Ligou mais duas vezes e a esposa afirmou que voltaria até de manhã, mas disse que ele também era responsável pelo cuidado com as meninas. O agressor contou que notou "sintoma de embriaguez na voz" dela.

Ele afirmou que ficou esperando a esposa para levar as meninas ao hospital, mas como ela não chegava e uma delas tossia, colocou-as no carro pois pretendia deixar uma com a avó e levar a outra ao médico. Pegou uma arma de fogo, colocou as filhas no carro, abriu o portão e saiu, retornando quando percebeu que havia deixado o portão da casa aberto. Nesse momento, antes de entrar novamente no veículo, a vítima chegou à casa. Ele contou que a vítima disse que não iria ao hospital com ele, que as crianças eram problema dele, além disso o xingou de canalha, vagabundo, falou que era irresponsável, e que iria voltar para a casa da amiga, porque estava melhor do que em casa. Em seguida, a vítima teria dado ré, xingado o companheiro, feito um gesto obsceno com a mão e ainda jogado o veículo em sua direção. Edgar teria conseguido se esquivar e nesse momento efetuou vários disparos contra Elaine, pois “temia por sua vida”. Não teria tentado matar o enteado, mas teve vontade de se matar. Ao tentar sacar a arma, esta disparou atingindo sua perna. Em suas palavras "estava triste por ela não tomar a postura de mãe e esposa, e triste por ela não ter voltado para casa, e ele ter duas crianças pequenas e ela não tomar a postura de mãe".

O agressor relatou que a vítima tinha, além dos dois filhos do casal, do enteado, da filha que vivia com eles, outro filho que ela teria dado para adoção. Acrescentou que cada um destes 
seria de pais diferentes. Além disso, pontuou novamente que a vítima era viciada em cocaína, e que ele teria acreditado que ela estava "limpa" durante o casamento, mas que suas atitudes o fizeram desconfiar que ela permanecia envolvida com o uso de drogas. Antes da decisão de pronúncia, o irmão da vítima foi interpelado pelo Ministério Público e informou que Elaine "bebia socialmente, mas não tinha problema com bebida". A amiga da vítima foi interpelada no mesmo sentido pelo promotor e disse que "conhecia a vítima há 20 anos e não tinha conhecimento do seu envolvimento com drogas". Diante das provas coletadas, o acusado foi pronunciado pelo homicídio duplamente qualificado da esposa, por motivo fútil e com uso de recurso que impossibilitou a defesa da vítima (art. 121, $₫ 2^{\circ}$, II e IV, CP) e, também, pela tentativa de homicídio do enteado.

No recurso da defesa contra a decisão de pronúncia, houve tentativa de afastar as qualificadoras do homicídio consumado sob o argumento de que a futilidade só ocorreria se o motivo do crime fosse banal, o que não teria ocorrido no caso, pois a vítima teria saído de casa pela manhã, deixado as filhas pequenas doentes e retornado à casa pela madrugada, depois de inúmeras tentativas do marido em falar com ela. Quanto ao crime de tentativa de homicídio, a defesa argumentou que o agressor nunca tentou matar o enteado e buscou afastar a versão de que a vítima teria colocado o braço na frente do atirador para salvar o filho, sob o argumento de que ela "não era dada a tais arroubos de amores por quem gerava. Doou filhos para estranhos, abandonou a caçula doente em casa no dia de sua morte, dirigindo-se a festas e bares, e somente passou a ter uma relação verdadeiramente de família, após o enlance com Edgar”. Em novo interrogatório, o réu novamente foi interpelado sobre a vida da vítima, e aproveitou para incluir novas informações sobre quem ela seria:

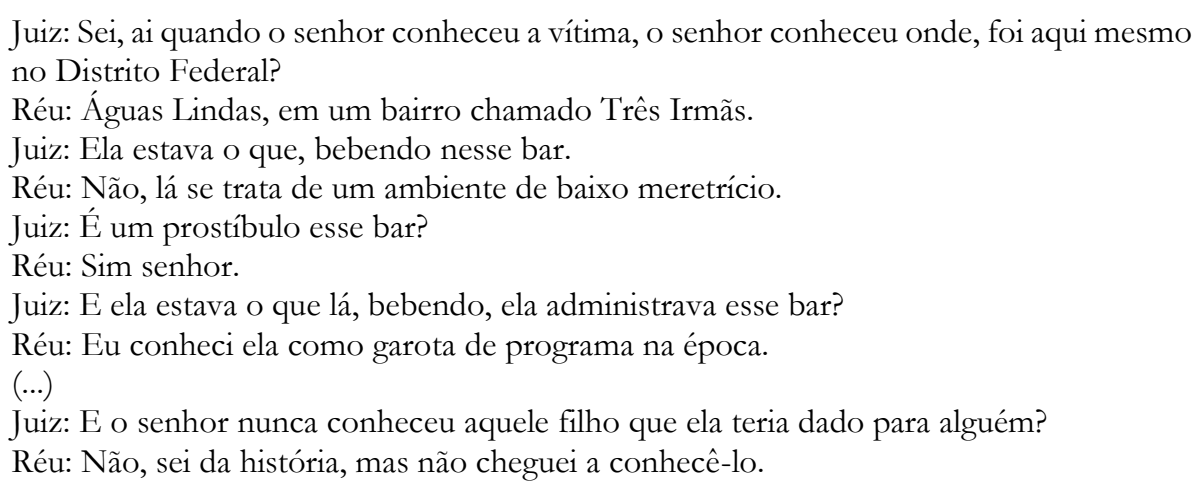

No interrogatório, o juiz interpelou o agressor sobre o suposto uso de drogas da vítima: 
Juiz: Em 2004, ah tá, ela parou de beber?

Réu: Antes do casamento sim, ai após a primeira filha ela passou a voltar a beber, a sair com familiares e sumir, passava dois dias fora, às vezes eu estava de plantão, por algum motivo me deslocar a minha casa, chegar ela já tinha saído, aparecia no dia posterior. Juiz: E as crianças, levava para onde?

Réu: Alguma vezes levava as crianças, deixava em casa de amigos, e algumas vezes deixava com a menor.

(...)

Juiz: A vítima tinha algum vício além da bebida, algum outro vício além da bebida?

Réu: Eu quando a conheci ela era viciada em cocaína

Juiz: Viciada mesmo ou...

Réu: Consumidora

Juiz: Consumidora

Réu: Porque para mim a pessoa experimentou...

Juiz O senhor disse quando a conheceu, isso quer dizer então que ela parou de usar?

Réu: Em 2001 quando eu voltei a me relacionar ela, ela ainda fazia uso

Juiz: Mas ai parou?

Réu: Em 2004 quando a gente chegou a casar, eu não tinha desconfiança dela nesse quesito, mas voltei a ter de um tempo para cá devido as saídas, as chegadas de madrugada, mas em 2005 quando eu decidi que me casar, 2004 quando eu resolvi casar e constituir família eu a considerava limpa, seria o termo.

A informação de que a vítima seria usuária de drogas e prostituta só apareceu no depoimento do acusado. Nenhuma das testemunhas, em nenhum momento, confirmou que a vítima tinha problemas com álcool, cocaína ou qualquer outra droga, ou que no passado trabalhou como prostituta. Não há nos autos qualquer prova nesse sentido, apenas a alegação do agressor. No entanto, em várias oportunidades os agentes da engrenagem punitiva retomaram o questionamento sobre o comportamento da vítima, especialmente o uso de drogas. No depoimento do enteado, antes do julgamento do júri, o uso de drogas voltou a ser objeto de questionamento:

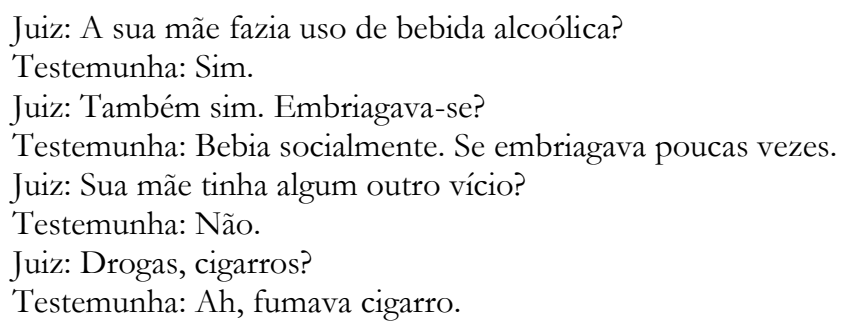

Houve uma insistência dos agentes da engrenagem punitiva em saber quem era a vítima e se ela era consumidora de drogas, mesmo tal fato sendo irrelevante para a configuração do crime e a punição do agressor. A busca por dar inteligibilidade ao feminicídio e justificar a conduta criminosa do agressor teve como fundamento o comportamento social da vítima. Ao longo da defesa do réu, a versão dos fatos foi modificada e cada vez mais foram agregadas informações que não tinham relação com o crime em si, mas trataram de fatos da ordem moral. Do ponto de vista da defesa, a estratégia foi mostrar que a ação do agressor, mesmo contrária as normas jurídicas, poderia ser considerada moralmente legítima. A vítima foi construída pelos discursos das práticas 
judiciárias como alguém que não estaria cumprindo com o seu destino social, ser mãe e esposa. Nesse sentido, a violência sofrida, se justificaria pelo disciplinamento patriarcal do marido. Seguindo essa linha defensiva, foi incluído um quesito para votação dos jurados sobre a caracterização do crime como um homicídio privilegiado: "o réu agiu sob o domínio de violenta emoção, logo em seguida à injusta provocação da vítima, consistente em agressões verbais e em sua conduta em demorar demasiadamente em retornar para casa a fim de cuidar de suas filhas que estavam doentes?" Na votação do júri, três jurados responderam que sim ao quesito, enquanto quatro responderam que não. Um jurado absolveu o agressor.

$\mathrm{Na}$ dosimetria da pena, o juiz se surpreendeu por se tratar de agressor policial e, por isso, considerou como elevada a culpabilidade do réu, tanto pela quantidade de disparos que efetuou, como pelo fato dele ocupar alto posto na "honrosa PMDF". Para ele, o réu teria se comportado de forma diversa da esperada, uma vez que os integrantes da PMDF deveriam ter "maior equilíbrio e capacidade de conter seus ímpetos de fúria", o que o réu não demonstrou possuir. Já quanto a conduta social, o juiz a considerou boa, pois o agressor era "bom pai de família, assumindo a criação e o sustento não só dos filhos do casal, como também os da própria vítima, frutos de outros relacionamentos". Era trabalhador e considerado bom policial, "a despeito do fato praticado e sob julgamento". Assim, o juiz considerou que não haveria possibilidade de manter o réu na PMDF, pois a sua conduta era "incompatível com a missão institucional de salvaguardar a vida e a incolumidade física das pessoas", e foi decretada a perda de seu cargo público.

A defesa recorreu e em seu recurso de apelação afirmou que o casal vivia "entre tapas e beijos" e que o comportamento da vítima teria sido decisivo para a ocorrência da tragédia. Novamente reforçaram que não seria normal uma mulher sair para beber e deixar a filha doente em casa, não atender ao marido e retornar a casa de madrugada com sintomas de embriaguez. Assim, o motivo do crime não seria banal, e a vítima tampouco teria sido surpreendida:

\footnotetext{
"Qual a futilidade no ato de um marido ensandecido pelo ciúme, com um histórico matrimonial de sofrimento, após inúmeras vezes tentar contatar com sua mulher no telefone, ela não o atender, enquanto encontra-se em um bar bebendo, sabe-se lá com quem, em plena madrugada? era óbvio que a vítima esperava uma reação forte do marido."
}

O recurso da defesa não teve provimento e o agressor foi condenado a cumprir 22 anos e 08 meses de reclusão pelos dois crimes. 


\section{CASO 02}

No caso 02, Erika, 35 anos, conheceu Fernando, cabo do corpo de bombeiros militar do DF, 41 anos, em um bate - papo na internet quando então passaram a namorar. ${ }^{26} \mathrm{O}$ relacionamento durou cerca de quatro anos, mas era "conturbado", marcado por "idas e vindas". ${ }^{27}$ Erika estava insatisfeita com o relacionamento e tentou diversas vezes romper o namoro, mas Fernando não aceitava e insistia para reatarem. Ele frequentemente a seguia e também a ameaçava de morte, "se ela não ficasse com ele não ficaria com mais ninguém". ${ }^{28}$ Em um desses episódios, ele enviou uma foto com a arma apontada para a própria cabeça e uma foto dos dois filhos da vítima na mão. No testemunho do irmão, ele afirma que Erika continuava no relacionamento porque temia por sua vida e pela de seus filhos. Nunca o denunciou porque não queria prejudicálo perante a corporação. ${ }^{29}$

De acordo com a denúncia, no dia dos fatos, o casal saiu para jantar, e, quando Fernando foi deixar Erika em casa, ouviu mais uma vez que a relação estava acabada. Não conformado com o fim do relacionamento, ele pegou o revólver que estava debaixo do banco do carro e desferiu um tiro na cabeça dela. Em seguida, levou o corpo à delegacia e confessou o crime. Em seu testemunho consta que ele agiu assim, pois "percebeu que a relação dos dois chegara ao fim". Fernando confessou não só a autoria do crime, mas também o dolo de matar, e foi denunciado por homicídio duplamente qualificado, por motivo torpe e mediante recurso que dificultou a defesa da vítima (art. 121, $\$ 2^{\circ}$, I e IV, do CP).

O delegado de polícia representou pela prisão preventiva do agressor, tendo como justificativa a manutenção da ordem pública, pelo clamor social que o crime causou, bem como pela conveniência da instrução criminal, levando em conta o risco que Fernando solto representaria, especialmente aos familiares da vítima. O crime "bárbaro", "perpetrado contra uma mãe de família de apenas 35 anos de idade, com uma vida inteira pela frente e dois filhos para serem criados", foi visto como a prova da monstruosidade do agressor:

O seu ato somente demonstra seu lado doentio, insano, sociopata, pois não existe maior
vileja que ceifar a vida de uma pessoa somente porque esta não quer mais manter
relacionamento consigo. Causa perplexidade, asco, nojo, imaginar que um ser humano,
num único gesto, possa arrebatar a vida de outra pessoa a esferas ainda por nós
desconhecidas, retirando-a do convívio de seus familiares, de modo truculento,

\footnotetext{
${ }^{26}$ Nomes retirados da notícia: Polícia prende bombeiro militar que matou a ex- mulher. Notícia urbana, 16 jul. 2015. Disponível em: <http://noticiaurbana.com.br/policia-prende-bombeiro-militar-fernando-penna/>. Acesso em: 06 mar. 2017.

27 Termo de declarações da amiga da vítima.

28 Termo de declarações do padrasto da vítima.

${ }^{29}$ Termo de declarações da amiga da vítima.
} 
inimaginável ao credo comum e, mais, não permitindo sequer que a vítima pudesse valerse de qualquer defesa, pois foi um tiro a queima- roupa.

O delegado ainda entendeu que haveria uma discrepância na conduta do bombeiro: a agressão praticada em casa não condiria com a conduta de um agente encarregado da manutenção da lei e da ordem pública. Para o delegado, esse era um elemento negativo a ser considerado, pois mesmo se tratando de cabo do corpo de bombeiros, ele não teve "qualquer receio em transgredir as normas incriminadoras vigentes, agindo como se estivesse acima da lei, como se esta lhe fosse inatingível". Nesse sentido, acrescentou que a conduta seria dotada de "ínsita periculosidade", e que o crime seria revestido de "malvadez, perversão, e insensibilidade, pondo em risco a ordem pública”, o que tornaria necessária à sua prisão. O fato de o agressor ter matado a namorada e ser bombeiro militar o tornou um indivíduo perigoso.

O pedido do Ministério Público para a prisão preventiva foi no mesmo sentido. O promotor afirmou que a ordem pública estaria abalada, "a sociedade revoltada com a barbárie", o que tornariam necessárias medidas para impedir que ficasse no ar "uma sensação de impunidade, notadamente envolvendo um dos seus privilegiados agentes militares". A decisão do juiz foi favorável à prisão preventiva do agressor, levando em consideração que a periculosidade demonstrada no crime "bárbaro" praticado, que tornou "órfãos dois filhos, deixando ainda enlutada a família da vítima", foi prova da insensibilidade do agressor perante a vida alheia. Os fatos graves exigiriam do judiciário medidas imediatas para preservar a ordem pública.

Após a confissão na delegacia, Fernando foi liberado pelos policiais e entregue à responsabilidade do Corpo de Bombeiros (CBMDF), na pessoa do seu supervisor. Ele passou por avaliação do psicólogo do CBMDF, que verificou a necessidade de sua internação, em razão da "alta probabilidade" de suicídio. Dessa forma, foi encaminhado a uma clínica psiquiátrica para tratamento de saúde mental. Após a expedição do mandado de prisão preventiva ele seguiu internado na clínica, mas sob escolta e vigilância da corporação. Depois de liberado, foi recolhido nas instalações do Núcleo de Custódia da Polícia Militar. Em seu primeiro interrogatório em juízo, afirmou que não teria condições de narrar o que ocorreu no dia dos fatos, uma vez que estava fazendo uso de medicamentos. A defesa do agressor pediu a instauração do incidente de insanidade mental, sob a justificativa de que o crime seria grave, de que o agressor teria demonstrado falta de lógica e de que não soube explicar o ocorrido. Assim, "a fim de sanar dúvidas sobre a sua capacidade de entendimento e autodeterminação" o exame psiquiátrico foi autorizado pelo judiciário. 
Para as práticas judiciárias importou saber quem o agressor era, não apenas a nível de seus atos, mas a nível de suas virtualidades. Para determinar não apenas o que ele fez, mas quem ele era e o que ele poderia fazer (FOUCAULT, 2009), nos autos foram juntados saberes de poderes laterais e instaurado o incidente de insanidade mental. No incidente de insanidade mental, o parecer psicológico do agressor revelou "personalidade com dificuldades afetivas, sem caracterizar quadro psicopatológico passível de comprometer suas condições de análise da realidade.” E que o periciando "não apresenta, nem apresentava à época do fato em questão, transtorno mental que comprometesse suas capacidades de entendimento e autodeterminação". A sua periculosidade não estaria, portanto, "vinculada a transtorno mental".

Já as referências à vítima foram no sentido de mostrar que o seu comportava era adequado as normas do gênero: boa mãe, cuidadora e dedicada à família. No depoimento da mãe da vítima, o Ministério Público a interpelou nesse sentido:

MP: Dona M. como era a Erika em família?

Testemunha: Muito bem relacionada com a família e muito querida pela família MP: E com os filhos?

Testemunha: (ininteligível) da mesma maneira

MP: da mesma maneira?

Testemunha: Da mesma maneira. Muito querida adorava os filhos, vivia para os filhos, trabalhava e era uma pessoa que vivia para o trabalho, para a família e para os filhos.

Em seu interrogatório, o réu mudou a versão dos fatos. Afirmou que quando foi deixar a vítima em casa, após terem jantado, Erika teria dito para manterem contato e ele respondeu que ela deveria atendê-lo quando ligasse, porque senão ele ficaria achando que ela estaria com outra pessoa. A vítima teria dito "se eu tiver o que que tem?" e ele respondeu que iria tirar a própria vida se isso ocorresse. Pegou a arma e colocou na própria direção, momento em que ela disse que se ele quisesse se matar, que se matasse. Fernando então teria dito que a mataria antes e apontou a arma já engatilhada para Erika. Ela se assustou e bateu com o cotovelo na arma, que, acidentalmente, disparou contra ela.

$\mathrm{Na}$ votação do júri, nenhum dos jurados absolveu o réu e foi mantida a incidência das qualificadoras do motivo torpe e da surpresa. Para o cálculo da pena do agressor, o juiz considerou que "as consequências do crime foram perniciosas", uma vez que Fernando tirou a vida de "uma mulher, mãe de dois filhos ainda criança em idade de cinco e nove anos, que experimentaram alguns sérios danos emocionais", além de terem sido "privados da presença materna de forma prematura". O juiz registrou ainda que não havia nos autos menção ao comportamento da vítima que teria 
contribuído para a conduta violenta do réu. A construção da vítima como mãe pelas práticas judiciárias foi levada em consideração para a punição do agressor.

O agressor permaneceu preso durante todo o desenrolar processual e ao final foi condenado a 19 anos e 6 meses de reclusão pela morte da namorada. A dissonância construída pelas práticas judiciárias entre ser um agente da segurança e agressor voltou à cena do julgamento quando, após ser condenado pelo júri, o juiz na dosimetria da pena considerou a culpabilidade alta, pois por ser bombeiro militar há muitos anos, "agente da segurança pública compromissado com a preservação de vidas", ele, com a sua conduta criminosa, "desprezou a sua missão e violou a existência de uma pessoa que dizia amar". O fato de ser bombeiro militar e ter cometido o crime de feminicídio o tornou um indivíduo perigoso para toda sociedade. Dessa forma, além da pena privativa de liberdade, o juiz decretou a perda de seu cargo público.

A defesa apelou e sustentou a versão do agressor de que a vítima teria batido na arma com o braço, fazendo-a disparar em sua direção. Nesse sentido, a decisão dos jurados mereceria reforma, porque não haveria o dolo de matar no caso, mas sim culpa consciente. ${ }^{30}$ Sucessivamente, pediu o afastamento das qualificadoras e a diminuição da pena pelas circunstâncias favoráveis presentes: o agressor era réu primário, possuidor de bons antecedentes, boa conduta social, bombeiro militar classificado com ótimo comportamento, confessou espontaneamente e teria demonstrado profundo arrependimento. Nas contrarrazões do Ministério Público, foi afirmado que o comportamento da vítima em nada contribuiu para o cometimento do crime, sendo a culpabilidade do agressor bastante grave e acentuada, uma vez que agiu com intenso dolo, quando lhe era exigida uma conduta totalmente diversa da praticada, por se tratar de bombeiro militar. $\mathrm{O}$ recurso não teve provimento e foi mantida a condenação a 19 anos e 06 meses de reclusão.

\section{CASO 03}

No processo 03, Dário, capitão da polícia militar do DF, e Yana, mantinham relacionamento amoroso há 11 anos, moravam juntos e tinham 3 filhas em comum. ${ }^{31} \mathrm{O}$

\footnotetext{
${ }^{30}$ Diferente do dolo, que se configura quando o agente age com vontade que o resultado do crime ocorra, na culpa consciente o agente prevê o resultado da sua conduta, mas confia que ele não irá acontecer. Neste último, o agente não quer o resultado e nem assume o risco de produzi-lo (BITENCOURT, 2011).

${ }^{31}$ Notícias retiradas da notícia: Capitão da PM que matou a esposa divide uma cela com outro preso no Creed, 04 jan. 2013. Blog Diário de Pernambuco. Disponível <http://blogs.diariodepernambuco.com.br/segurancapublica/?p=2263>. Acesso em: 06 mar. 2017.
} 
relacionamento entre eles era problemático ${ }^{32}$ e consta no processo de feminicídio inúmeros boletins de ocorrência referentes a episódios anteriores de violência, desde 08 anos antes da morte da vítima, em que ela denunciou ameaças e agressões físicas sofridas. Em uma das ocorrências, no testemunho prestado pela vítima, constava que o casal teria rompido o relacionamento e, desde então, ela estaria sofrendo com as constantes ameaças de morte proferidas por ele. Nessa ocasião, ele teria lhe agredido com um caco de vidro e lhe ameaçado dizendo que "se ela ficasse com outro iria matá-la, que ele poderia fazer o que quisesse, pois ninguém o tiraria da polícia militar e que se não a matasse sabia quem poderia fazer o serviço por ele".

A denúncia relatou que no dia dos fatos, a irmã da vítima, a vítima e o agressor foram a uma festa durante o dia, na qual Dário consumiu cocaína e bebidas alcoólicas. Quando saíram da festa, os três foram até a casa da mãe da vítima para buscar as filhas do casal, mas o agressor disse que queria sair novamente e a vítima respondeu que não iria. $\mathrm{O}$ agressor saiu do carro, pegou o revólver que estava no porta-luvas e disparou contra a vítima, que ainda estava dentro do automóvel. Ele fugiu do local do crime, mas depois se apresentou na delegacia. O Ministério Público pediu a prisão preventiva do agressor sob o argumento de que o vasto histórico de violência doméstica e familiar mostrava que se tratava de "pessoa violenta e perigosa" que deveria ser afastada do convívio social como forma de preservar a ordem pública. O juiz decretou a prisão preventiva do agressor.

Familiares da vítima presenciaram o desfecho trágico e o testemunho prestado pela irmã foi importante para estabelecer a verdade do ocorrido. No entanto, outros testemunhos foram produzidos como forma de dar inteligibilidade a ação do agressor. No testemunho de um amigo do casal, constava que ele já teria presenciado a vítima jogar cerveja no rosto do réu, desferir tapas no rosto dele e ameaçá-lo com arma de fogo. Além disso, o amigo relatou que a vítima em uma ocasião teria ido até o bar onde o agressor estaria bebendo e dado um tapa na cara dele. Nesse dia, o agressor não teria sido violento com a vítima, mas mesmo assim ela teria comparecido à delegacia com marcas de hematomas no corpo para denunciá-lo. Para o amigo, seria impossível o réu ter causado tais ferimentos, pois nesse dia Dário não teria “triscado a mão" em Yana. Além disso, ele teria presenciado a vítima trair o réu numa festa e depois tê-lo chamado de corno, dizendo que a filha mais nova tinha outro pai.

No testemunho da dona do bar que conhecia o casal, consta que Yana e Dário mantinham um "relacionamento turbulento", pois ambos eram muito ciumentos e que aconteciam

\footnotetext{
32 Termos de declaração da irmã da vítima
} 
muitas agressões verbais entre eles, "mais por parte da vítima". Ela conta que a vítima já teria jogado cerveja no rosto do réu e que em sua perspectiva a vítima se irritava porque o agressor bebia com os amigos no bar. A vítima teria também lhe confessado que pretendia abortar e colocar a culpa no acusado, pois estaria grávida e não teria certeza de quem seria o pai. Por isso, pretendia tomar remédio abortivo e depois ir à delegacia informar que o agressor foi quem lhe deu os medicamentos.

No interrogatório do réu, ele contou que no dia dos fatos, quando voltaram da festa, ele e a vítima discutiram porque ela teria amassado a lataria do carro. Durante a discussão, a vítima lhe disse que ele era "corno, chifrudo e vagabundo" e o ameaçou dizendo que ia dar um tiro na cabeça dele. Ela teria aberto o porta-luvas do carro e pegado a bolsa com o revolver. Nesse momento, o réu se atracou com a vítima e conseguiu pegar o revólver, mas ela teria continuado a ofendê-lo, uma vez que afirmou que a filha mais nova não era dele e que ele seria "corno". Quando ela disse que iria morar com o pai da criança, ele perdeu a cabeça e deu diversos tiros nela. Em seu depoimento, Dário confessou o uso de drogas, mas justificou que usava porque "estava deprimido e em razão dos problemas com a vítima”.

Nas alegações finais, a defesa buscou responsabilizar a vítima e o agressor pelo ocorrido, naturalizando o histórico de violência, de forma a afastar a incidência das qualificadoras no crime de homicídio. Em suas alegações finais, argumentou que o relacionamento do casal era repleto de muitas agressões, falta de respeito entre ambos e que uma tragédia era esperada por amigos e familiares. Assim, "o histórico de agressões recíprocas, e o próprio temor dos familiares de que as constantes brigas poderiam terminar em tragédia, são motivos suficientes para afastar a qualificadora de surpresa”. Já o motivo fútil deveria ser afastado, pois a relação entre eles era conturbada e a vítima também já teria agredido o agressor. A defesa pediu que o réu fosse colocado em liberdade, pois como bom policial militar não representaria risco para a sociedade.

O réu foi pronunciado por infração ao art. 121, $₫ 2^{\circ}$, II e IV, do Código Penal e condenado pelo conselho de sentença por essa mesma infração. Um jurado, no entanto, votou que se tratava de homicídio privilegiado e outros dois consideraram que não havia motivo fútil no crime. No momento da dosimetria da pena, o juiz togado levou em consideração a profissão do agressor para considerar que a sua culpabilidade destoaria do esperado, pois como agente de segurança deveria combater a criminalidade e não a incrementar. Ele foi considerado como indivíduo perigoso e construído pelas práticas judiciárias como uma exceção dentro do aparato policial. O juiz fixou a pena base em 13 anos e 06 meses de reclusão. Pela presença da atenuante 
da confissão, que considerou preponderante em relação a agravante da violência doméstica, a pena definitiva foi de 13 anos de reclusão.

Tanto a defesa como o Ministério Público apelaram. O primeiro requereu a cassação do julgamento, sob o fundamento de a decisão ser contrária as provas dos autos e sucessivamente a instauração de incidente de insanidade mental, para desresponsabilizar o agressor, ou caso não fosse verificada a sua inimputabilidade, fosse diminuída a pena aplicada. Nenhum dos pedidos da defesa foi julgado procedente. Quanto ao segundo apelante, o Ministério Público requereu o aumento da pena aplicada. Nesse ponto, o relator em seu voto considerou a culpabilidade como grave por se tratar de policial militar que fazia uso de drogas, especialmente a cocaína. Para ele, o agressor tinha uma "vida desregrada, divorciada completamente do comportamento escorreito que se espera de um policial militar." Além disso, teria matado a esposa. Foi considerado como circunstância do crime, o fato de que houve recurso que dificultou a defesa da vítima, e por ter o delito sido praticado na presença dos filhos e da mãe da vítima. O magistrado considerou que, como não houve trânsito em julgado de nenhuma das condenações por violência doméstica, esta agravante não poderia ser preponderante à confissão. De forma que as duas foram compensadas e a pena final foi definida em 15 anos de reclusão.

Em todos os três casos, não bastou saber que a ação do agressor se enquadrou na proibição legal, foi necessário construir a partir dos discursos das práticas judiciárias quem o agressor era e quem a vítima era. No caso 01 , o suposto comportamento social da vítima, mesmo sem relação com o acontecimento criminoso e sem qualquer prova de veridição nos autos, ganhou relevância nos discursos porque estaria em desacordo com as normas sociais esperadas de uma mulher. A vítima foi construída como uma mulher viciada em drogas, promíscua, que não cumpriu com as expectativas normativas de mãe e esposa. Assim, a construção da vítima pelos discursos das práticas judiciárias provocou dúvidas no júri quanto a legitimidade do feminicídio e o seu reconhecimento como vítima. Dessa forma, um jurado se convenceu que a punição justa para o caso seria a absolvição do agressor e outros de que esse seria um crime privilegiado.

O mesmo ocorreu no processo 03, em que foram juntados aos autos testemunhos que construíram a vítima como uma mulher mentirosa, que traía o agressor e queria prejudicá-lo por meio de falsas acusações de crime. Mesmo com a condenação do júri, houve dúvidas se o crime seria um homicídio privilegiado e se houve motivo fútil. Já no caso 02 , diferente dos outros, o agressor confessou não apenas a autoria do crime, mas também o dolo de matar. Além disso, ao longo do processo ele foi construído como louco. Já a vítima foi construída como boa mãe, 
trabalhadora e dedicada à família. Nesse caso, o reconhecimento da mulher como vítima não legitimou moralmente a ação do agressor, que foi construído como indivíduo monstruoso.

Nos três casos, as mulheres vítimas de violência doméstica e familiar tornaram-se também vítimas da violência institucional da engrenagem punitiva, uma vez que as práticas judiciárias construíram um saber - poder sobre elas que expressou e reproduziu discriminações baseadas nas normas do gênero. Se no âmbito doméstico e familiar as mulheres foram punidas por seus maridos, companheiros e ex- parceiros pelos desvios de comportamento e sofreram com o disciplinamento patriarcal, no âmbito da engrenagem punitiva não houve rupturas, o braço punitivo funcionou de forma integrada à família, e expressou e reproduziu a ordem patriarcal (ANDRADE, 2005; DINIZ; VIEIRA, 2017). Mesmo com a punição dos agressores a penas altas, a engrenagem punitiva produziu discursos em um marco patriarcal de poder.

Apesar de testemunhas da violência do gênero, as mulheres, supertestis, não nos contam quem eram, nem as suas histórias e nem o que ocorreu, já que não houve sobreviventes nos casos estudados. Por isso, os testis têm um papel relevante para o estabelecimento da verdade pelas práticas judiciárias, de forma que eles são interpelados ao longo de todo o processo para a produção do saber- poder não apenas sobre o crime, mas também sobre os sujeitos envolvidos. A produção da vítima implicou em permanente retorno às normas do gênero inauguradas com a sexagem original das mulheres, de forma que elas foram julgadas quanto a sua conformidade às performances de mães, esposas e cuidadoras. Não houve neutralidade nos testemunhos, estes foram produzidos sob uma moral patriarcal. Quanto aos agressores, as práticas judiciárias os construíram em contraponto as vítimas: quando elas eram construídas em desconformidade com as normas do gênero, eles eram construídos como bons pais, profissionais dedicados e provedores. Já quando o contrário ocorria - quando as vítimas se adequavam as normas do gênero - os agressores foram construídos como sujeitos monstruosos.

O fato de os agressores serem agentes da segurança e defesa do Estado foi levado em conta pela engrenagem punitiva para puni-los mais. Em todos os casos, não houve proteção dos agressores, ao contrário, o fato de terem cometido feminicídios causou surpresa e levou as práticas judiciárias a construí-los como desvios dentro das instituições. O saber individualizante das práticas judiciárias penais utiliza como campo de referência não só o crime cometido, mas as virtualidades do indivíduo (FOUCAULT, 2010). Assim, o desacordo da atitude violenta contra a mulher com a profissão exercida foi utilizado para produzi-los como indivíduos perigosos para toda sociedade. Essa estratégia parece ser uma forma de manter o problema da violência na casa e não ampliar a 
discussão sobre violência do gênero para dentro das instituições do Estado. Ao restringir o entendimento dos feminicídios, a moral patriarcal que moveu os assassinatos das mulheres continuou sendo atualizada pela engrenagem punitiva, nos discursos produzidos pela prática judiciária.

\subsection{CASOS DE FEMINICíDIO - SUICÍDIO}

Nos casos de feminicídio - suicídio, após as investigações policiais chegarem à conclusão de que o agressor que cometeu o feminicídio se suicidou em seguida, os inquéritos foram arquivados e o desfecho do crime se deu com a extinção da punibilidade pela morte do agente. ${ }^{33} \mathrm{~A}$ produção da verdade envolveu especialmente o aparato policial, já que estes são casos que não chegaram à fase do processo judicial, e o trabalho da polícia foi o de investigar o crime e dar inteligibilidade às mortes. Os casos não exigiram extensa investigação para concluírem sobre a autoria do feminicídio, pois o suicídio do agressor ocorreu imediatamente após as mortes das vítimas e o cenário das mortes indicava o ocorrido. Assim, os testemunhos de familiares, amigas, vizinhas, do agressor e da vítima, além dos laudos das perícias técnicas foram importantes elementos para o estabelecimento da verdade. As perícias técnicas se encarregaram de examinar o local da morte, os corpos cadavéricos, as armas utilizadas, de forma a concluírem que o agressor que morreu é o mesmo que matou a vítima. Já os testemunhos dos testis foram necessários para dar inteligibilidade aos crimes.

Os seis casos de feminicídio - suicídio do arquivo são bem similares e vão ao encontro do que a literatura internacional sobre o tema identificou como o cenário das mortes. ${ }^{34}$ Os agressores são homens, as vítimas são mulheres e a motivação do crime é atribuída ao fato de os homens não aceitarem o fim do relacionamento (HARPER, 2007; GREGORY, 2012; FERNÁNDEZ TERUELO, 2011; KOZIOL-MCLAIN et al, 2006; LIEM, 2010; LIEM et al., 2011). Nenhum destes estudos problematiza que a motivação do crime se relaciona à violência do

\footnotetext{
33 "Art. 107 - Extingue-se a punibilidade:

I - pela morte do agente” (BRASIL, 1940).

${ }^{34}$ Para a revisão de literatura sobre feminicídio - suicídio considerei não apenas os estudos que utilizavam essa nomenclatura, mas também utilizei na busca as palavras-chave "homicídio - suicídio", "murder - suicide" "homicide followed by suicide". Isso porque entendo feminicídio como uma categoria política que designa os homicídios de mulheres pelo regime do gênero, de forma que era necessária a leitura dos artigos para identificar quais se enquadravam dentro do universo em estudo e quais não.
} 
gênero, em que mulheres são vistas como propriedades dos homens. A construção da verdade do feminicídio - suicídio seguiu essa mesma narrativa.

\section{CASO 04}

No caso 04, Danilo, ex- soldado da PMDF, matou a facadas a sua esposa Valquíria e em seguida se enforcou com uma corda. ${ }^{35}$ Danilo e Valquíria eram casados há 24 anos e tinham 03 filhos em comum. No testemunho da filha mais velha constou que os pais se conhecerem quando o pai tinha 14 anos e a mãe 12 anos, e "não conseguiam viver um sem o outro". Durante o casamento, o agressor foi preso pela prática de homicídio e, nesse período, Valquíria cuidou dos filhos e visitou com frequência o marido encarcerado. Quando Danilo foi liberado da prisão, passou a trabalhar com a esposa na venda de bolsas e calçados, mas exigiu o recebimento de metade da pensão que ela recebia por ele ser militar. A partir disso, começaram os desentendimentos do casal.

Valquíria decidiu separar-se de Danilo, mas ele não aceitou o fim do relacionamento e passou a ameaçá-la de morte caso ela não ficasse com ele. Em um desses episódios, ele teria tentado matá-la com o uso de arma de fogo, mas foi impedido pelos filhos. Danilo então saiu da casa que compartilhava com a família, mas em uma manhã surpreendeu a vítima em sua residência e a esfaqueou diversas vezes na frente do filho caçula. A criança teria tentado impedir o pai, mas este o ameaçou de morte também. Após a morte da esposa, Danilo se enforcou com uma corda. No testemunho do irmão do agressor, ele relata que o casal não era de brigar e que Danilo era apaixonado por Valquíria. Os desentendimentos teriam começado a ocorrer por causa da pensão que ela recebia. Além disso, na opinião dele e de outros familiares, o feminicídio - suicídio teria ocorrido por Danilo gostar muito de Valquíria e não aceitar a separação.

\footnotetext{
35 Nomes retirados da notícia: Ex- PM mata mulher, sogros e cunhado. Estadão, 06 dez. 2012. Disponível em: $<$ http://sao-paulo.estadao.com.br/noticias/geral,ex-pm-mata-mulher-sogros-e-cunhado-imp-,969819>. Acesso em: 06 mar. 2017.
} 


\section{CASO 05}

No processo 05, Júnior, policial civil, e Gislaine, eram casados e retratados como um casal fechado, sendo que pouco se sabia sobre eles. ${ }^{36} \mathrm{O}$ testemunho dos testis é dado apenas pelos vizinhos, que conseguiam ouvir as brigas e acompanhar o dia- a - dia do casal. Em um dos relatos constava que o agressor teria dito para a vítima, dias antes de matá-la por disparos de arma de fogo, "se você não for minha, não será de mais ninguém". No dia dos fatos, Júnior e Gislaine participaram de audiência de separação, o que teria deixado o policial transtornado e o motivado a cometer o duplo feminicídio- suicídio.

\section{CASO 06}

No caso 06, o inquérito do feminicídio-suicídio relata - a partir dos testemunhos de vizinhas - as constantes brigas entre o capitão da polícia militar, Jaime, e sua esposa Alexia. $\mathrm{Na}$ delegacia, apurou-se que já existiam registros de violências anteriores sofridas pela vítima. ${ }^{37}$

As considerações do relatório policial informam que a vítima teria registrado duas ocorrências anteriores, de crimes de ameaça, injúria e violação ao domićlio, e em que informava que o marido teria lhe dito que iria matá-la e depois se mataria. A vítima teria dito que o marido era "ciumento, agressivo, possessivo" e que não aceitava a separação proposta por ela, o que ocasionava humilhações e agressões físicas contra ela. Apesar das ocorrências anteriores, a vítima havia manifestado o desejo de arquivar as medidas protetivas e os inquéritos policiais.

Ainda que a investigação do caso atribua a motivação do crime ao fim do relacionamento, o arquivo também considera a vítima como responsável pelo fim trágico - uma vez que Alexia não deu continuidade aos processos contra o marido.

No relatório final do inquérito de feminicídio - suicídio, o delegado de polícia afirmou que

"Ressalte-se que a vítima Edjane já havia noticiado nesta circunscricional em duas ocorrências policiais ameaças de morte por parte de Jaime as quais foram devidamente

\footnotetext{
${ }^{36}$ Nomes tirados da notícia: Investigador da polícia mata mulher e comete suicídio no interior de SP. Portal G1, 08 dez. 2016. Disponível em: <http://g1.globo.com/sao-paulo/itapetininga-regiao/noticia/2016/12/investigador-dapolicia-mata-mulher-e-comete-suicidio-no-interior-de-sp.html>. Acesso em: 06 mar. 2017.

${ }^{37}$ Nomes retirados da notícia: PM é suspeito de matar companheira e se suicidar em Glorinha, no RS. Portal G1, 05 dez. 2015. Disponível em: <http://g1.globo.com/rs/rio-grande-do-sul/noticia/2016/12/pm-e-suspeito-de-matarcompanheira-e-se-suicidar-em-glorinha-no-rs.html>. Acesso em: 06 mar. 2017.
} 
apuradas pela Seção de Atendimento à Mulher - DAM desta DP, contudo a própria vítima se retratava das representações e continuava a conviver com seu agressor".

\section{CASO 07}

No processo 06, Eliomar, policial rodoviário federal, e Ana Maria, namoravam há 04 anos, sendo que pouco se sabe sobre o relacionamento entre eles. ${ }^{38}$ Os pais da vítima foram os testis que forneceram o testemunho do ocorrido, descrevendo a vítima como uma menina alegre e estudiosa; já ele, como um rapaz fechado e sério. Os pais relataram que Ana Maria viajou e terminou o relacionamento com Eliomar por telefone. Quando retornou, ele foi visitá-la, ocasião em que atirou nela e em seguida em si mesmo. Os corpos foram encontrados no banheiro da casa dos pais dela. Os pais da vítima afirmaram que nunca haviam tomado conhecimento sobre qualquer situação de violência anterior entre eles.

No exame de local de morte violenta, a perícia examinou não apenas a casa dos pais da Ana Maria, mas também o veículo do agressor. No banco direito do carro, foram encontrados quatro cartões vermelhos, cortados na forma de coração com mensagens de Ana Maria para Eliomar. O primeiro dizia, "Parabéns para a gente! 1 ano e 6 meses, Te amo!", o segundo, “MMMVACK!! 1 ano e 7 meses! Te amo por tudo Eliomar!”, o terceiro, "Haha!! Você é mais que perfeito! 1 ano e 9 meses! Te amo! Beijos!!” e o quarto, "Vou sentir muita saudade, Eliomar! Te amo! Juízo!". Ao fim da perícia, os peritos concluíram que os cartões encontrados mostravam que Eliomar e Ana Maria mantinham um relacionamento amoroso. E que o último cartão parecia ser de fim de relacionamento e que "isso poderia ter motivados as ações de Eliomar". Na decisão pelo arquivamento do inquérito, o juiz concluiu que "Eliomar desiludido com o rompimento do relacionamento resolveu por fim a vida de Ana Maria e da própria vida”.

\section{CASO 08}

No caso 08, Luis Carlos, policial civil, matou sua esposa, Márcia, com disparos de arma de fogo e em seguida se matou com a mesma arma. ${ }^{39}$ Dois sobrinhos e o cunhado da vítima

\footnotetext{
${ }^{38}$ Nomes retirados da notícia: Inspetor da PRF atira na mulher e se mata em Cariacica. Folha Vitória, 24 jan. 2017. Disponível em: <http://www.folhavitoria.com.br/policia/noticia/2011/01/inspetor-da-prf-atira-na-mulher-e-semata-em-cariacica.html>. Acesso em: 06 mar. 2017.

${ }^{39}$ Nomes retirados da notícia: Policial civil mata a mulher e comete suicídio em seguida no Sul de Minas. Portal UAI, 05 agos. $2012 . \quad$ Disponível em: <http://www.em.com.br/app/noticia/gerais/2012/08/05/interna_gerais,310103/policial-civil-mata-a-mulher-ecomete-suicidio-em-seguida-no-sul-de-minas.shtml>. Acesso em: 06 mar. 2017.
} 
presenciaram todo o desfecho trágico. Luis Carlos e Márcia eram casados há 22 anos e tinham 2 filhos em comum. De acordo com o testemunho dos familiares, o casal vivia um relacionamento tranquilo até que o agressor sofreu um infarto e mudou o seu comportamento, pois passou a apresentar quadro depressivo e muita agressividade. A situação piorou quando a vítima confessou em uma brincadeira de "jogo da verdade” que há 15 anos havia se relacionado com um colega de trabalho. A vítima só teria contado a traição, porque o agressor também havia revelado ter sido infiel durante o casamento.

Após esse episódio, Luis Carlos teria ficado mais violento com Márcia, além de agredila fisicamente, a expulsou de casa. Márcia foi morar com a irmã, o cunhado e os filhos destes, mas frequentemente visitava a sua família, sendo que nessas oportunidades voltava para casa da irmã com hematomas no corpo. O casal começou a fazer terapia e estava tentado se reconciliar. No dia dos fatos, Luis Carlos participou de uma competição a cavalo com saltos, mas caiu no primeiro obstáculo. Isso o deixou enfurecido e muito agressivo com o cavalo, sendo necessário contê-lo para que parasse de bater no animal. Após a competição, ele foi para casa, tomou medicação para se acalmar e dormiu em seguida. A vítima estava com ele, mas retornou a casa da irmã quando Luis Carlos adormeceu.

A filha do casal informou que quando o pai acordou estava muito irritado e agressivo. Ele saiu de casa e foi atrás de Márcia na casa da cunhada. O agressor se dirigiu à vítima e perguntou por que ela teria saído sem sua permissão, tendo em seguida desferido um soco em seu rosto. $\mathrm{O}$ cunhado interviu, mas Luis Carlos disse que não estava lá para conversar e atirou entre as pernas dele para mostrar que não estava de brincadeira. Luis Carlos foi em direção a mulher e deu vários disparos nela. Quando estava saindo do quarto, apontou a arma para a própria cabeça e disparou.

Os policiais civis chamados à cena dos crimes para investigar o ocorrido registraram, ao chegar ao local, que Luis Carlos era "agente de polícia lotado nesta unidade policial”. A verdade é produzida pelos mesmos agentes que conviviam e trabalhavam com o agressor. Diferente dos outros, não foi a separação do casal que motivou a ocorrência do feminicídio- suicídio. No testemunho dos filhos do casal e da irmã da vítima, o motivo do crime estaria relacionado ao fato de Márcia ter revelado a traição durante o casamento. A produção da verdade gira em torno da traição da esposa e da instabilidade emocional do agressor, que estaria apresentando quadro depressivo e violento. A honra manchada de Luis Carlos foi a motivação para o assassinato da mulher. 
De acordo com o testemunho do sobrinho, quando Luis Carlos olhou para Márcia caída no chão, "demonstrou um outro semblante, como se estivesse arrependido do que havia feito. Que neste instante, Luis Carlos apontou a arma para a própria cabeça, fez uma feição de medo, e apertou o gatilho, caindo em seguida". O arquivo registra Luis Carlos como um homem desequilibrado, traído, que mata a esposa, se arrepende e depois se mata.

\section{CASO 09}

Luís Cláudio, cabo do exército, de 30 anos, e Cristiane, de 32 anos, eram casados e tinham um filho em comum. Pouco se sabe do relacionamento entre eles, nem a família, nem amigos sabiam detalhes da convivência do casal. ${ }^{40}$ Uma vizinha contou que já havia presenciado uma briga entre os dois meses antes do desfecho trágico, quando encontrou Cristiane chorando no portão de casa com marcas de agressão física no corpo e Luís Cláudio muito exaltado. Já no testemunho do pai do agressor, havia o relato de que as brigas eram sempre por ciúmes, pois Luís Cláudio era músico e, por isso, "muito visado pelas mulheres". Além disso, durante algumas discussões o casal se agredia, mas o pai de Luis Cláudio nunca tomou conhecimento de que o filho tivesse agredido fisicamente ou ameaçado Cristiane.

Pouco antes do feminicídio, a vítima separou-se do agressor e foi morar na casa da irmã mais nova. Nos termos de declaração do irmão da vítima, ele contou que Cristiane havia agendado horário na defensoria pública para promover uma ação de separação litigiosa, uma vez que o seu marido não concordava com o rompimento do relacionamento entre eles. As duas irmãs, antes disso, foram à delegacia, pois a vítima queria registrar a ameaça que sofreu quando o casal discutia a separação e Luís Cláudio a ameaçou dizendo: "se você sair de casa e for para a casa de seus pais eu vou fazer da sua vida um inferno". No entanto, na delegacia não conseguiu registrar a ocorrência. Os agentes disseram a ela que a expressão proferida por Luís Cláudio seria uma "ameaça condicional" e que não configuraria crime. Poucos dias depois, a vítima, acompanhado agora pelo irmão, foi de novo a delegacia, mas novamente não conseguiu registrar a ocorrência, porque "se tratava de uma ameaça condicional, que não configura crime e que não cabia registro".

Nesse mesmo dia, a vítima e o irmão consultaram um promotor de justiça que os orientou a voltarem à delegacia, porque as palavras proferidas pelo agressor se enquadrariam em

\footnotetext{
40 Nomes retirados da notícia: Sargento do Exército mata a mulher e se suicida em Deodoro. O Dia, 19 fev. 2014. Disponível em: < http://odia.ig.com.br/noticia/rio-de-janeiro/2014-02-19/sargento-do-exercito-mata-a-mulher-e-sesuicida-em-deodoro.html>. Acesso em: 06 mar. 2017.
} 
um crime de ameaça, de forma que poderiam requerer medidas protetivas. Os dois voltaram à delegacia e, de acordo com o testemunho do irmão, incialmente "percebeu nos agentes de polícia uma certa insistência no argumento de que não configurava crime". Ele conversou com o delegado de plantão, que explicou que para ser ameaça o autor teria de ter dito: "vou fazer da sua vida um inferno", suprimindo a condicionante "se". Mas, nesse dia, ficou decidido que se fosse a vontade da vítima, eles registrariam a ocorrência. Nessa oportunidade, a vítima narrou que o agressor não estava auxiliando no sustento dela e de seu filho.

"Os policiais do plantão explicaram que caso a investigação fosse aberta Luís Cláudio
acabaria sendo prejudicado no trabalho, por ser cabo do exército, uma vez que cópia da
investigação seria inexoravelmente remetida ao seu oficial superior. Os agentes não
chegaram a falar que caso fosse registrada a ocorrência Luís Cláudio seria preso. No
entanto tanto o declarante quanto os agentes perceberam que Cristiane ficou receosa de
dar início a investigação e acabar prejudicando Luís Cláudio no trabalho por causa de seu
filho. E. estava desempregada e deve ter ficado com bastante receio de Luís Cláudio ser
preso ou perder seu cargo no Ministério do Exército." (termo de declarações do irmão
da vítima).

No entanto, a vítima ficou receosa em denunciar o marido, e resolveu se informar melhor na defensoria para decidir o que fazer antes de registrar ocorrência contra o marido. Nessa noite, ela ficou na casa de seus pais, pois teria que abrir uma conta bancária para instruir o processo de separação e de pensão alimentícia. No dia seguinte, pela manhã, o agressor foi à casa dos pais da vítima, procurando pelo filho. Cristiane foi conversar com ele, momento em que Luís Cláudio efetuou dois disparos de arma de fogo contra ela e em seguida um contra si mesmo.

Em todos os casos analisados, o arquivo constrói a verdade dos feminicídios suicídios como crimes da paixão. Os feminicídios - suicídios são produzidos como crimes que ocorreram numa relação amorosa porque o agressor não aceitava viver sem a mulher amada e não suportava a ideia de que ela pudesse ter outro homem. Na tradição jurídica brasileira, alguns homicídios eram chamados de passionais, pois seriam decorrentes da paixão. Estes eram casos que ocorriam em um relacionamento amoroso, em que o homem matava a mulher, seja em razão da separação ou da traição e que eram aceitos socialmente em razão do papel do homem em corrigir os desvios da mulher. Os discursos das práticas judiciárias do arquivo, mesmo sem referência aos homicídios passionais ou as legislações que legitimavam as desigualdades do gênero, são permeados por uma "memória social de longa duração" (MACHADO, 2009, p. 58), em que é naturalizada a ideia de que a mulher é propriedade do homem.

Os crimes passionais significavam o reconhecimento pelo ordenamento jurídico da legitimidade dos assassinatos de mulheres por homens em um relacionamento amoroso, por 
motivos relacionados a apropriação das mulheres como algo natural e inscrito no marco do destino biológico (GUILLAUMIN, 2005). O direito legitimava o regime político do gênero e reproduzia desigualdades sociais. Assim, os passionais não eram considerados como indivíduos perigosos, mas como aqueles que haviam corrigido o comportamento inadequado da mulher que manchara a sua honra (BORELLI, 2005). O suicídio ou a sua tentativa eram consideradas provas de insanidade temporária e da irresponsabilidade dos homens, mas também mostravam que estes estavam desesperados e "ansiavam por uma união romântica na morte" (HARRIS, 1993, p. 317). Como nos casos de feminicídio - suicídio, o discurso utilizado para dar inteligibilidade aos crimes passionais era relacionado a paixão e não ao patriarcado.

O caso 09 se diferenciou pelo vestígio deixado no arquivo sobre o que ocorreu antes da morte da vítima e que mostrou o não reconhecimento pelo aparato policial da narrativa da mulher sobre a violência praticada pelo marido, nas diversas vezes em que buscou proteção. A forma como a vítima foi tratada, as falas dos policiais, as perguntas feitas, mostraram como a polícia operou no tratamento da violência e também do seu lugar de poder de dizer a verdade da violência. No caso, houve inúmeras negativas de reconhecimento da narrativa da vítima pelos policiais, as ameaças e violências praticadas por seu marido não foram reconhecidas como um discurso legítimo por quem tem o lugar de poder de transformar esse testemunho em um discurso de verdade. $\mathrm{O}$ fato de o marido ser cabo do exército influenciou a avaliação do testemunho pelos policiais, que se moveram pela proteção de um dos seus agentes de segurança e defesa do Estado ao invés da vítima.

A verdade produzida pelos agentes da engrenagem punitiva seguiu o entendimento de que esse seria um crime da paixão, que ocorreu porque o agressor não queria viver sem a vítima. Não é explorada a desproteção da mulher pelo aparato policial - que não legitimou a violência sofrida pela vítima. No pedido de arquivamento do inquérito pelo Ministério Público, consta que “o casal” vivia uma relação conturbada e que já haviam se separado algumas vezes. O MP afirmou que a vítima teria procurado a delegacia de polícia e só não representou "temendo que tal fato prejudicasse Walter em seu serviço e, consequentemente, no sustento de seu filho". Além disso, afirmou que "o casal" teria histórico de brigas e até mesmo já haviam chegado às vias de fato. $\mathrm{O}$ juízo decretou o arquivamento do processo e seguiu o entendimento do MP de que "o casal tinha histórico de desavenças, inclusive o que ensejaria sua separação litigiosa, a ser requerida pela vítima". A possível desproteção vivida pela vítima dias antes de sua morte é encoberta pela sua responsabilização pela "relação conturbada" e violenta que vivia com o marido. 
Nos casos de feminicídio - suicídio a verdade produzida pelas práticas judiciárias é a de que esses seriam crimes passionais, em que o agressor matava e se matava por não querer viver sem a mulher amada. A mulher é construída como propriedade do homem e ele a mata pela paixão. Os discursos ao utilizarem o imaginário de crimes passionais naturalizam a ideia de que a mulher é apropriada pelo marido nas relações do gênero. A polícia foi o principal agente a construir a verdade dos feminicídios - suicídios como crimes passionais. 


\section{CONSIDERAÇÕES FinAIS}

No presente estudo busquei problematizar como a engrenagem punitiva produziu a verdade dos feminicídios quando se tratava de agressores que eram agentes da segurança e defesa do Estado. Da análise dos processos, verifiquei que a profissão dos agressores não foi levada em consideração pela engrenagem punitiva para proteção dos mesmos, ou seja, não houve tentativa de diminuição da punição ou de defesa dos agressores com base no seu papel de agente do Estado. Ao contrário, os agressores foram considerados indivíduos perigosos por serem agentes da segurança e defesa do Estado que cometeram feminicídios. A profissão dos agressores serviu para mostrar o desacordo da conduta criminosa com a instituição da qual eles pertenciam, de forma que os agressores foram considerados indivíduos perigosos para toda sociedade por terem cometido um crime do gênero.

A produção da verdade dos casos foi realizada sob uma moral patriarcal, uma vez que os discursos utilizados para legitimar os crimes foram da ordem moral patriarcal e buscaram justificar a conduta do agressor a partir do desvio da vítima às normas sociais determinadas às mulheres. Os discursos das práticas judiciárias construíram um saber- poder sobre as vítimas, com base nas normas do gênero, de forma que elas foram julgadas quanto a sua conformidade às performances de mães, esposas e cuidadoras. As mulheres, vítimas de violência doméstica e familiar, tornaramse também vítimas da violência institucional da engrenagem punitiva. Quanto aos agressores, as práticas judiciárias os construíram em contraponto as vítimas, quando elas eram construídas em desconformidade com as normas do gênero, eles eram construídos como bons pais, profissionais dedicados e provedores. Já quando o contrário ocorria, os agressores foram construídos como sujeitos monstruosos. Ainda que em todos os casos os agressores foram punidos a penas altas e os discursos utilizados mostraram que a engrenagem punitiva se movimentou por uma moral patriarcal.

No mesmo sentido nos casos de feminicídio - suicídio, a produção da verdade mostrou que houve um revigoramento da ideia de crimes da paixão, ainda que não tenha sido utilizada a mesma linguagem do passado. A verdade produzida pelas práticas judiciárias é a de que esses seriam crimes passionais, em que o agressor matava e se matava por não querer viver sem a mulher amada. Os discursos naturalizaram a ideia de que a mulher é apropriada pelo marido nas relações do gênero. 
Assim, a leitura patriarcal dos feminicídios produziu a verdade desses crimes como violência de homens na casa e só foi levado em consideração que os agressores eram agentes da segurança e defesa do Estado para puni-los mais. A violência do gênero foi naturalizada pela leitura patriarcal das mortes de mulheres, de forma que as camadas de complexificação da violência foram ignoradas. A estratégia utilizada foi a de individualizar nos agentes a conduta cometida, construindo os agressores como exceções à regra dos agentes da segurança e defesa do estado. Os feminicídios foram compreendidos como crimes da casa, o que não permitiu que a discussão da violência fosse levada para as instituições do Estado. Essa estratégia prejudicou a problematização da violência doméstica e familiar para além do espaço doméstico, já que o agressor foi lido só pela moral patriarcal e não por sua investidura de poder policial. Para tratar a violência doméstica como um problema público e pensar respostas à violência que se adequem aos diferentes cenários vivenciados pelas mulheres, é necessário também ampliar a discussão sobre violência do gênero para além do espaço doméstico. 


\section{REFERÊNCIAS}

AGAMBEN, Giorgio. O que resta de Auschwitz: o arquivo e a testemunha (homo saccer III). São Paulo: Boitempo, 2008.

ALCOFF, Linda. The problem of speaking for others. Cultural Critique. Vol. 20, N. 20, 1991: 5 -32 .

ALFONSÍN, JOSEFINA; MIRANDA, Juliana. Femicidio institucional - Muertes de mujeres por razones de género como problema de violencia institucional en el Área Metropolitana de Buenos Aires (2010-2015). II Congresso Latinoamericano delito y sociedad. Santa Fe, Argentina: 2015

AMMONS, Jennifer. Batterers with Badges: Officer-Involved Domestic Violence. Women Lawyers Journal, v. 90, p. 28-39, 2005.

ANDRADE, Vera R. Criminologia e Feminismo: da mulher como vítima à mulher como sujeito de construção da cidadania. In: CAMPOS, Carmen Hein (org). Criminologia e Feminismo. Porto Alegre: editora sulina, 1999.

A soberania patriarcal: o sistema de justiça criminal no tratamento da violência sexual contra a mulher. Revista Seqüência, nº 50, p. 71-102, jul. 2005.

ANIS - Instituto de Bioética. O impacto dos laudos periciais no julgamento de homicídio de mulheres em contexto de violência doméstica ou familiar no Distrito Federal. In: Homicídios no Brasil: registro e fluxo de informações. Brasília: Ministério da Justiça, Secretaria Nacional de Segurança Pública (SENASP), 2013. 409 p.: il. - (Coleção Pensando a Segurança Pública; v. 1).

\section{$<$ http://www.mpdft.mp.br/portal/pdf/nucleos/nucleo genero/publicacoes/Pesquisa ANIS R adiografia homicidios violencia domestica.pdf>. Acesso em: 23 fev. 2017.}

ARDAILLON, Danielle; DEBERT, Guita Grin. Quando a vítima é mulher: análise de julgamentos de crimes de estupro, espancamento e homicídio. Brasília: Conselho Nacional dos Direitos da Mulher, 1987.

BARBOSA, Adilson J. P.; FOSCARINI, Léia T. Do atendimento da autoridade policial - artigos 10 a 12. In: CAMPOS, Carmen Hein de (org). Lei Maria da Penha comentada em uma perspectiva jurídico - feminista. Rio de Janeiro: Lumen Iuris, 2011.

BANDEIRA, Lourdes. Três décadas de resistência feminista contra o sexismo e a violência feminina no Brasil: 1976 a 2006. Sociedade e Estado, v. 24, n. 2, p. 401-438, 2009.

BARATTA, Alessandro. Criminología y sistema penal (compilación in memoriam). Montevideo: B de F, 2004.

O paradigma do gênero: Da questão criminal à questão humana. In: CAMPOS, Carmen Hein (org). Criminologia e Feminismo. Porto Alegre: Editora Sulina, 1999.

BARTLETT, Katharine T. Métodos Jurídicos Feministas. In: FERNÁNDEZ, Marisol; MORALES Félix. Métodos feministas en el derecho: aproximaciones críticas a la jurisprudencia peruana. Lima: Palestra, 2011. 
BITTNER, Egon. Aspectos do Trabalho Policial. São Paulo: Editora da Universidade de São Paulo, 2003.

BLUMENSTEIN, Lindsey; FRIDELL, Lorie; JONES, Shayne. The link between traditional police sub-culture and police intimate partner violence. Policing: An International Journal of Police Strategies \& Management, v. 35, n. 1, p. 147-164, 2012.

BORELLI, Andrea. Da privação dos sentidos à legítima defesa da honra: considerações sobre o direito e a violência contra as mulheres. Revista Brasileira de Ciências Criminais, São Paulo, v. 13, n. 54, p. 9-42, maio/jun. 2005.

BOURDIEU, Pierre. "Crítica da razão escolástica"; "As três formas do erro escolástico". Meditações Pascalinas. Trad. Sergio Miceli. Rio de Janeiro. Bertrand do Brasil, 2001: 19 - 112.

BRASIL, 1890. Decreto nº. 847, 11 de outubro de 1890. Promulga o Código Penal. Disponível em: <http://legis.senado.gov.br/legislacao/ListaPublicacoes.action?id=66049>. Acesso em: 06 mar. 2017.

BRASIL. Decreto-lei $\mathrm{n}^{\circ}$ 2.848, de 7 de dezembro de 1940. Código Penal. Disponível em: $<$ http://www.planalto.gov.br/ccivil_03/decreto-lei/Del2848compilado.htm>. Acesso em: 23 fev. 2017.

BRASIL. Constituição da República Federativa do Brasil de 1988, de 5 de outubro de 1988. Diário Oficial da República Federativa do Brasil, 5 out. 1988. Disponível em: $<$ http://www.planalto.gov.br/ccivil_03/constituicao/constituicaocompilado.htm>. Acesso em: 28 fev. 2017.

BRASIL. Lei no 9.099, de 26 de setembro de 1995. Dispõe sobre os Juizados Especiais Cíveis e Criminais e dá outras providências. Diário Oficial da União, 27 set. 1995. Disponível em: <http://www.planalto.gov.br/ccivil_03/leis/L9099.htm>. Acesso em: 04 de mar. 2017.

BRASIL. Lei $\mathrm{n}^{\circ}$ 11.340, de 7 de agosto de 2006. Cria mecanismos para coibir a violência doméstica e familiar contra a mulher, nos termos do $\int 8^{\circ}$ do art. 226 da Constituição Federal, da Convenção sobre a Eliminação de Todas as Formas de Discriminação contra as Mulheres e da Convenção Interamericana para Prevenir, Punir e Erradicar a Violência contra a Mulher; dispõe sobre a criação dos Juizados de Violência Doméstica e Familiar contra a Mulher; altera o Código de Processo Penal, o Código Penal e a Lei de Execução Penal; e dá outras providências. Diário Oficial da República Federativa do Brasil, 08 ago. 2006. Disponível em: <http://www.planalto.gov.br/ccivil_03/_ato2004-2006/2006/lei/111340.htm>. Acesso em: 23 fev. 2017.

BRASIL. Lei n. 12.527, de 18 de novembro de 2011. Regula o acesso a informações previsto no inciso XXXIII do art. 5o, no inciso II do $\int 30$ do art. 37 e no $\ 20$ do art. 216 da Constituição Federal; altera a Lei no 8.112, de 11 de dezembro de 1990; revoga a Lei no 11.111, de 5 de maio de 2005, e dispositivos da Lei no 8.159, de 8 de janeiro de 1991; e dá outras providências. Diário Oficial da República Federativa do Brasil, 18 nov. 2011. Disponível em: <http://www.planalto.gov.br/ccivil_03/_ato2011-2014/2011/lei/112527.htm>. Acesso em: 28 fev. 2017.

BRASIL. Ministério da Saúde. Conselho Nacional de Saúde (CNS). Resolução n. 466, de 12 de dezembro $2012 . \quad$ De em: 
<http://bvsms.saude.gov.br/bvs/saudelegis/cns/2013/res0466_12_12_2012.html>. Acesso em: 28 fev. 2017.

BRASIL. Lei n. 13.104, de 09 de março de 2015. Altera o art. 121 do Decreto-Lei no 2.848, de 7 de dezembro de 1940 - Código Penal, para prever o feminicídio como circunstância qualificadora do crime de homicídio, e o art. $1^{\circ}$ da Lei no 8.072, de 25 de julho de 1990, para incluir o feminicídio no rol dos crimes hediondos. Diário Oficial da República Federativa do Brasil, 10 de março de 2015. Disponível em: <http://www.planalto.gov.br/ccivil 03/Ato20152018/2015/lei/L13104.htm>. Acesso em: 04 mar. 2017.

BRASIL. Lei n. 13.105, de 16 de março de 2015. Código de Processo Civil. Disponível em: <http://www.planalto.gov.br/ccivil 03/ ato2015-2018/2015/lei/113105.htm>. Acesso em: 28 fev. 2017.

CAPUTI, Jane; RUSSEL, Diana E. H. Femicide: Sexist Terrorism against Women. In: Radford, Jill; Russel, Diana E. H. Femicide: The Politics of Woman Killing. New York: Twayne, 1992

CAMPOS, Carmen Hein de. Juizados Especiais Criminais e seu déficit teórico. Estudos Feministas, Florianópolis, 11(1): 336, jan-jun/2003, p. 155-170.

Feminicídio no Brasil: Uma análise crítico-feminista. Sistema Penal \& Violência, Porto Alegre, v. 7, n. 1, p. 103-115, jan.-jun. 2015

CAMPOS, Carmen H. CARVALHO, Salo. Violência doméstica e juizados especiais criminais: análise a partir do feminismo e do garantismo. Revista de Estudos Femininos, Florianópolis, v. 14, n. 2, mai-set. 2006.

Capitão da PM que matou a esposa divide uma cela com outro preso no Creed. Blog Diário de

Pernambuco, 04 jan. 2013. Disponível em: $<$ http://blogs.diariodepernambuco.com.br/segurancapublica/?p=2263>. Acesso em: 06 mar. 2017.

CARDOSO, Renata Braz das Neves. Homens autores de violência contra parceiros íntimos: estudo com policiais militares do Distrito Federal. Dissertação (Mestrado em Desenvolvimento, Sociedade e Cooperação Internacional). Universidade de Brasília, Brasília, 2016.

CASTILHO, Ela Wiecko Volkmer de. A Lei 11.340/06 e as novas perspectivas da intervenção do estado para superar a violência de gênero no âmbito doméstico e familiar. In: SANTOS, Luiz Felipe Brasil (Coord.). Lei Maria da Penha - Lei no 11.340/06 e Lei de Tóxicos - Lei no 11.343/06: 2o ciclo de estudos. Porto Alegre: Tribunal de Justiça do Rio Grande do Sul. Departamento de Artes Gráficas, 2007.

Direito penal em debate - Sobre o feminicídio. Boletim do IBCCrim no 270, Maio/2015.

CORREAA, Mariza. Morte em família: representações jurídicas de papéis sexuais. Rio de Janeiro: Edições Graal, 1983.

DAS, Veena. Sujetos del dolor, agentes de dignidad. Bogotá: Universidad Nacional de Colombia. Facultad de Ciencias Humanas: Pontificia Universidad Javeriana. Instituto Pensar, 2008.

DEBERT, Guita Grin; OLIVEIRA, Marcella Beraldo De. Os modelos conciliatórios de solução de conflitos e a "violência doméstica". Cadernos Pagu, n. 29, p. 305-337, 2007. 
DINIZ, Debora. Perspectivas e articulações de uma perspectiva feminista. In: STEVENS, Cristina; OLIVEIRA, Susana Rodrigues de; ZANELLO, Valeska (Org.). Estudos feministas e de gênero: articulações e perspectivas. Brasília: Editora Mulheres, 2014. p. 10-21.

"Feminismo: modos de ver e mover-se". O que é feminismo? Escolar Editora, Lisboa. 2015a: $47-60$.

"Introdução. Etnografia e políticas da vida". Didier Fassin entrevistado por Debora Diniz. Coleção Pensamento Contemporâneo. Trad. Debora Diniz. Rev. Ana Terra e Soraya Fleischer. Rio de Janeiro. EdUERJ. 2015b.

Ela, Zefinha - o nome do abandono. Ciencia \& sau $\square$ de coletiva, v. 20, n. 9, p. 26672674, set. 2015c.

Cadeia: relatos sobre mulheres. Rio de Janeiro: Civilização Brasileira, 2015d.

DINIZ, Debora; COSTA, Bruna S.; VIEIRA, Sinara G. Nomear feminicídio: conhecer, simbolizar e punir. Revista Brasileira de Ciências Criminais. São Paulo, nº. 114, maio - junho. 2015: 225 $-239$.

DINIZ, Debora; VIEIRA, Sinara G. Violência do gênero no Brasil: ambiguidades da política criminal, 2017. No prelo.

DINIZ, Simone G. "Violência contra a mulher: estratégias e respostas do movimento feminista no Brasil (1980-2005)", In: DINIZ, C.S.G.; SILVEIRA, L.P.; MIRIM, L.A.L. Vinte e cinco anos de respostas brasileiras em violência contra a mulher: Alcances e Limites. São Paulo: Coletivo Feminista Sexualidade e Saúde, 2006.

DIOS, Vanessa Canabarro. A palavra da mulher: práticas de produção de verdade nos serviços de aborto legal no Brasil. Tese (Doutorado em Ciências da Saúde). Universidade de Brasília, Brasília, 2016.

ELUF, Luiza Nagib. A paixão no banco dos réus: casos passionais célebres: de Pontes Visgueiro a Pimenta Neves. $3^{a}$ ed. São Paulo: Saraiva, 2007.

Ex- PM mata mulher, sogros e cunhado. Estadão, 06 dez. 2012. Disponível em: <http://saopaulo.estadao.com.br/noticias/geral,ex-pm-mata-mulher-sogros-e-cunhado-imp-,969819>.

Acesso em: 06 mar. 2017.

FARGE, Arlette. O sabor do arquivo. Tradução de Fátima Murad. São Paulo: Editora da Universidade de São Paulo, 2009.

FASSIN, Didier. The humanitarian politics of testimony: subjectification through Trauma in the Israeli - Palestinian Conflict. Cultural Anthropology, Vol. 23, Issue 3, pp. 531-558.

FERNÁNDEZ TERUELO, Javier Gustavo. Feminicidios de género: Evolución real del fenómeno, el suicidio del agresor y la incidencia del tratamiento mediático. Revista Española de Investigación Criminológica, v. 1, p. 1-27, 2011.

FONSECA, Lívia Gimenes Dias da Fonseca. A luta pela liberdade em casa e na rua: a construção do direito das mulheres a partir do projeto Promotoras Legais Populares do Distrito Federal. Dissertação (Mestrado em Direito). Universidade de Brasília, Brasília, 2012. 
Fórum Brasileiro de Segurança Pública. 9 Anuário Brasileiro de Segurança Pública, 2015. Disponível em< http://www.forumseguranca.org.br/storage/9_anuario_2015.retificado_.pdf> Acesso em 01 fev. 2017.

FOUCAULT, Michel. A verdade e as formas jurídicas. $3^{a}$ ed., Rio de Janeiro: NAU Editora, 2009.

Vigiar e Punir: nascimento da prisão. 38ª ed., Petrópolis, RJ: Vozes, 2010.

GARCIA, Leila Posenato. A magnitude invisível da violência contra a mulher. Epidemiol. Serv.

Saúde, Brasília, v. 25, n. 3, pp. 451-454, set. 2016. Disponível em $<$ http://scielo.iec.pa.gov.br/scielo.php?script=sci_arttext\&pid=S1679-

$49742016000300451 \& \operatorname{lng}=$ pt\&nrm=iso >. Acesso em: 23 fev. 2017.

GUILLAUMIN, Colette. "Práctica del poder e idea de Naturaleza". In : Curiel, Ochy e Falquet, Jules (organizadores). El patriarcado al desnudo. Tres feministas materialistas. Buenos Aires, 2005.

GREGORY, Marilyn. Masculinity and homicide-suicide. International Journal of Law, Crime and Justice, v. 40, n. 3, p. 133-151, 2012.

GRINOVER, Ada P. et al. Juizados Especiais Criminais: comentários à Lei 9.099, de 26.09.1995. $5^{a}$ edição revista, atualizada e ampliada. São Paulo: Editora Revista dos Tribunais, 2005.

HARPER, Dee Wood. An Integrated Theoretical Perspective. Homicide Studies, v. 11, n. 4, p. 295-318, 2007.

HARRIS, Ruth. Assassinato e loucura: medicina, leis e sociedade no fin de siècle. Rio de Janeiro: Rocco, 1993.

Investigador da polícia mata mulher e comete suicídio no interior de SP. Portal G1, 08 dez. 2016. Disponível em: <http://g1.globo.com/sao-paulo/itapetiningaregiao/noticia/2016/12/investigador-da-policia-mata-mulher-e-comete-suicidio-no-interior-desp.html>. Acesso em: 06 mar. 2017.

Inspetor da PRF atira na mulher e se mata em Cariacica. Folha Vitória, 24 jan. 2017. Disponível em: <http://www.folhavitoria.com.br/policia/noticia/2011/01/inspetor-da-prf-atira-na-mulhere-se-mata-em-cariacica.html>. Acesso em: 06 mar. 2017.

JOHNSON, L.B. On the Front Lines: Police Stress and Family Well-Being. Hearing before the Select Committee on Children, Youth, and Families House of Representatives: 102 Congress First Session on Children, Youth, and Families House of Representatives. Washington DC: US Government Printing Office, 1991.

JOHNSON, Leanor Boulin; TODD, Michael; SUBRAMANIAN, Ganga. Violence in police families: Work-family spillover. Journal of Family Violence, v. 20, n. 1, p. 3-12, 2005.

KOZIOL-MCLAIN, Jane et al. Risk factors for femicide-suicide in abusive relationships: results from a multisite case control study. Violence and victims, v. 21, n. 1, p. 3-21, 2006.

LAGARDE, Marcela. Antropología, feminismo y política: violencia feminicida y derechos humanos de las mujeres. In: Bullen, Margaret; Mintegui, Carmen Diez (Org.). Retos teóricos y nuevas prácticas. Donostia: AnkulegiAntropologiaElkartea, 2008. p. 209-239. 
LIEM, Marieke. Homicide followed by suicide: A review. Aggression and Violent Behavior, v. 15, n. 3, p. 153-161, 2010.

LIEM, Marieke et al. Homicide-suicide and other violent deaths: An international comparison. Forensic Science International, v. 207, n. 1-3, p. 70-76, 2011.

MACHADO, Lia Z. Atender vítimas: criminalizar violências, dilemas das Delegacias da Mulher. Série Antropológica, n. 319. Brasília: UnB, Departamento de Antropologia, 2002.

A Longa Duração da Violência de Gênero na América Latina. In: Fernandes, Ana Maria, Ranincheski, Sonia (Orgs.) Américas Compartilhadas. $1^{a}$ Ed. São Paulo: Editora Francis, v.1, 2009 , p. 57-83.

MATOS, Myllena Calazans de; CORTES, Iáris. O processo de criação, aprovação e implementação da Lei Maria da Penha. In: CAMPOS, Carmen Hein de (org). Lei Maria da Penha comentada em uma perspectiva jurídico - feminista. Rio de Janeiro: Lumen Iuris, 2011.

MUNIZ, Jacqueline. Os direitos dos outros e outros direitos: um estudo de caso sobre a negociação de conflitos nas DEAMs/RJ. In: Soares, L. E. (org.). Violência e política no Rio de Janeiro. Rio de Janeiro: ISER/Relume Dumará, 1996. Disponível em: $<$ http://estudosdeseguranca.blogspot.com.br/2008/07/os-direitos-do-outros-e-outrosdireitos.html>. Acesso em 06 ago. 2016.

NEIDIG, Peter $\mathrm{H}$ et al. Interspousal Aggression in Law Enforcement Families: A Preliminary Investigation. Police Studies, Vol. 15 (1), p. 30-38, 2015.

NOBRE, Maria T.; BARREIRA, César. Controle social e mediação de conflitos: as delegacias da mulher e a violência doméstica. Sociologias, Porto Alegre, ano 10, n 20, jul/ de. 2008, p. 138- 163.

NUCCI, Guilherme de Souza. Manual de processo penal e execução penal, 9ed. São Paulo: Editora Revista dos Tribunais, 2012.

OKIN, Susan Moller. Gênero, o público e o privado. Rev. Estud. Fem., Florianópolis, v. 16, n. 2, p. 305-332, 2008.

PANDJIARJIAN, V. "Balanço de 25 anos da legislação sobre a violência contra as mulheres no Brasil”, In: DINIZ, C.S.G.; SILVEIRA, L.P.; MIRIM, L.A.L. Vinte e cinco anos de respostas brasileiras em violência contra a mulher: Alcances e Limites. São Paulo: Coletivo Feminista Sexualidade e Saúde, 2006.

PASINATO, Wânia. Justiça para todos: os Juizados Especiais Criminais e a violência de gênero. Tese de doutorado (Sociologia). Programa de Pós- Graduação em Sociologia, do Departamento de Sociologia da Faculdade de Filosofia, Letras e Ciências Humanas da Universidade de São Paulo. São Paulo, 2003.

Delegacias de Defesa da Mulher e Juizados Especiais Criminais: mulheres, violência e acesso à justiça. Artigo apresentado no XXVIII Encontro da Associação Nacional de Pós Graduação em Ciências Sociais - ANPOCS. Caxambu, Minas Gerais, 26 a 28 de outubro de 2004.

Condições de Funcionamento das Delegacias Especializadas de Atendimento à Mulher (DEAMS) e Juizados de Violência Doméstica e Familiar contra a Mulher para aplicação da Lei 11.340/2006 (Lei Maria da Penha) nas capitais e no Distrito Federal. Relatório final de pesquisa. 
Observe - Observatório da Lei Maria da Penha, 2010. Disponível em: < http://www.observe.ufba.br/ARQ/Relatorio $\% 20$ apresent $\% 20 \mathrm{e} \% 20$ DEAMs.pdf $>$. Acesso em: 07 mar. 2017.

Novas abordagens sobre velhas propostas. Onde avançamos? Porto Alegre: Civitas, v. 10, p. $216-232,2010$.

. "Femicídios" e as mortes de mulheres no Brasil. Cadernos Pagu (37), julho-dezembro de 2011: 219-246.

PIMENTEL, Silvia; PANDJIARJIAN, Valéria; BELLOQUE, Juliana. "'Legítima defesa da honra': ilegítima impunidade dos assassinos: um estudo crítico da legislação e jurisprudência da América Latina. Cadernos Pagu, Campinas: Unicamp, p. 65-134, 2006.

PM é suspeito de matar companheira e se suicidar em Glorinha, no RS. Portal G1, 05 dez. 2015. Disponível em: <http://g1.globo.com/rs/rio-grande-do-sul/noticia/2016/12/pm-e-suspeito-dematar-companheira-e-se-suicidar-em-glorinha-no-rs.html>. Acesso em: 06 mar. 2017.

Policial mata mulher, fere filha de 3 anos e depois se mata no Rio de Janeiro. Correio 24 horas, 23 jul. 2016. Disponível em: <http://www.correio24horas.com.br/detalhe/brasil/noticia/policialmata-mulher-fere-filha-de-3-anos-e-depois-se-mata-no-rio-de-

janeiro/?cHash=abf1ebdf3723f28bfb148159df05fde3 >. Acesso em 05 mar. 2017.

Policial militar é preso em flagrante após matar a esposa em Taboão da Serra (SP). Notícias R7, 11 jun. 2016. Disponível em: <http://noticias.r7.com/cidade-alerta/videos/policial-militar-epreso-em-flagrante-apos-matar-a-esposa-em-taboao-da-serra-sp-11062016>. Acesso em: 06 mar. 2017.

Polícia prende bombeiro militar que matou a ex- mulher. Notícia urbana, 16 jul. 2015. Disponível em: <http://noticiaurbana.com.br/policia-prende-bombeiro-militar-fernando-penna/>. Acesso em: 06 mar. 2017.

Policial civil mata a mulher e comete suicídio em seguida no Sul de Minas. Portal UAI, 05 ago. $2012 . \quad$ Disponível em: <http://www.em.com.br/app/noticia/gerais/2012/08/05/interna_gerais,310103/policial-civilmata-a-mulher-e-comete-suicidio-em-seguida-no-sul-de-minas.shtml>. Acesso em: 06 mar. 2017.

Por não aceitar fim do namoro, policial militar mata namorada a tiros em São Paulo. Correio 24 horas, 12 jan. 2017.2 Disponível em: <http://www.correio24horas.com.br/detalhe/categoria/noticia/por-nao-aceitar-fim-donamoro-policial-militar-mata-namorada-a-tiros-em-saopaulo/?cHash=9043a0cdc23a4ca199629f8d193d40bd>. Acesso em: 05 mar.2017.

ROSEMBERG, André. A "cultura policial": um debate teórico - metodológico. In: Desafios à Segurança Pública: controle social, democracia e gênero. Marília: Oficina Universitária; São Paulo: Cultura Acadêmica, 2012.

SAFFIOTI, H. I. B. Violência Doméstica: questão de polícia e da sociedade. In: Corrêa, M. (org.) Gênero e Cidadania. Campinas-SP, Núcleo de Estudos de Gênero Pagu/Unicamp, Coleção Encontros, 2002. 
SANTOS, C. M Da Delegacia da Mulher à Lei Maria da Penha: Lutas feministas e políticas públicas sobre violência contra mulheres no Brasil, Oficina do CES n. ${ }^{\mathbf{3}}$ 301, Coimbra: Centro de Estudos Sociais, 2008.

Sargento do Exército mata a mulher e se suicida em Deodoro. O Dia, 19 fev. 2014. Disponível em: <http://odia.ig.com.br/noticia/rio-de-janeiro/2014-02-19/sargento-do-exercito-mata-amulher-e-se-suicida-em-deodoro.html>. Acesso em: 06 mar. 2017.

Secretaria de Políticas para Mulheres (SPM). Norma técnica de padronização das delegacias especializadas de atendimento às mulheres - DEAMS. Edição atualizada, 2010. Disponível em: $\quad$ http://www.spm.gov.br/lei-maria-da-penha/lei-maria-da-penha/norma-tecnica-depadronizacao-das-deams-.pdf. Acesso em: 06 ago. 2016.

SENADO FEDERAL. Relatório Final da Comissão Parlamentar Mista de Inquérito "Com a finalidade de investigar a situação da violência contra a mulher no Brasil e apurar denúncias de omissão por parte do poder público com relação à aplicação de instrumentos instituídos em lei para proteger as mulheres em situação de violência”. Brasília, Junho de 2013.

SGAMBELLURI, Robert. Police Culture, Police Training, and Police Administration: Their Impact on Violence in Police Families. Domestic Violence by Police Officers, 2000.

Sobrevivi... o relato do caso Maria da Penha. Compromisso e Atitude, 2012. Disponível em: $<$ http://www.compromissoeatitude.org.br/wp-

content/uploads/2012/08/cejil_resumorelatocasomariadapenha.pdf>. Acesso em: 06 ago. 2016.

VÍLCHEZ, Ana Isabel Garita. La regulación del delito de femicídio/feminicidio en América Latina y el Caribe. Panamá: ÚNETE, 2008. Disponível em: $<$ http://www.un.org/es/women/endviolence/pdf/reg_del_femicicidio.pdf>. Acesso em: 05 mar. 2017.

Você já ouviu falar sobre a "ideologia de gênero"?. Observatório Interamericano de Biopolítica, 10 mar. 2015. Disponível em: <http://biopolitica.com.br/index.php/artigos/40-voce-ja-ouviufalar-sobre-a-ideologia-de-genero>. Acesso em: 06 mar. 2017.

WAISELFISZ, Julio Jacobo. Mapa da Violência 2015. Homicídio de mulheres no Brasil. CEBELA. $\quad$ FLASCO/Brasil, 2015.2015 Disponível $<$ http://www.mapadaviolencia.org.br/pdf2015/MapaViolencia 2015 mulheres.pdf $>$. Acesso em: 23 fev. 2017.

YIN, Robert K. Pesquisa qualitativa do início ao fim. Trad. Daniel Bueno. Revisão Técnica: Dirceu da Silva. Porto Alegre: Penso, 2016. 